\title{
Western Lake Erie Basin: Soft-Data-Constrained, NHDPlus Resolution Watershed Modeling and Exploration of Applicable Conservation Scenarios
}

\author{
Haw Yen ${ }^{1 \dagger}$, Michael J. White ${ }^{2}$, Jeffrey G. Arnold ${ }^{2}$, S. Conor Keitzer ${ }^{3}$, Mari-Vaughn V. \\ Johnson ${ }^{4}$, Jay D. Atwood ${ }^{4}$, Prasad Daggupati ${ }^{5}$, Matthew E. Herbert ${ }^{6}$, Scott P. Sowa ${ }^{6}$, Stuart A \\ Ludsin $^{3}$, Dale M. Robertson ${ }^{7}$, Raghavan Srinivasan ${ }^{5}$, Charles A. Rewa ${ }^{8}$
}

${ }^{1}$ Blackland Research and Extension Center, Texas A\&M Agrilife Research, 720 East Blackland Road, Temple, Texas 76502, USA

${ }^{2}$ Grassland, Soil \& Water Research Laboratory, USDA-ARS, 808 East Blackland Road, Temple, Texas 76502 USA

${ }^{3}$ Aquatic Ecology Laboratory, Department of Evolution, Ecology, and Organismal Biology, The Ohio State University, 1314 Kinnear Rd., Columbus, OH 43212, USA

${ }^{4}$ Grassland, Soil \& Water Research Laboratory, Resources Assessment Division, USDA-NRCS, 808 East Blackland Road, Temple, Texas 76502 USA

${ }^{5}$ Spatial Science Laboratory, Texas A\&M University, Suite 221, 1500 Research Plaza, College Station, TX 77843, USA

6 The Nature Conservancy, Michigan Field Office, 101 East Grand River Ave, Lansing, MI 48906, USA

${ }^{7}$ Wisconsin Water Science Center, U.S. Geological Survey, 8505 Research Way, Middleton, WI 53562, USA

${ }^{8}$ Resources Assessment Division, USDA-NRCS, George Washington Carver Center, Beltsville, MD, 20705, USA

${ }^{\dagger}$ Corresponding author:

Haw Yen, Ph.D., Assistant Research Scientist

email: haw.yen@gmail.com; hyen@ brc.tamus.edu; Voice: (254) 774-6004 


\begin{abstract}
Complex watershed simulation models are powerful tools that can help scientists and policymakers address challenging topics, such as land use management and water security. In the Western Lake Erie Basin (WLEB), complex hydrological models have been applied at various scales to help describe relationships between land use and water, nutrient, and sediment dynamics. This manuscript evaluated the capacity of the current Soil and Water Assessment Tool (SWAT) to predict hydrological and water quality processes within WLEB at the finest resolution watershed boundary unit (NHDPlus) along with the current conditions and conservation scenarios. The process based SWAT model was capable of the fine-scale computation and complex routing used in this project, as indicated by measured data at five gaging stations. The level of detail required for fine-scale spatial simulation made the use of both hard and soft data necessary in model calibration, alongside other model adaptations. Limitations to the model's predictive capacity were due to a paucity of data in the region at the NHDPlus scale rather than due to SWAT functionality. Results of treatment scenarios demonstrate variable effects of structural practices and nutrient management on sediment and nutrient loss dynamics. Targeting treatment to acres with critical outstanding conservation needs provides the largest return on investment in terms of nutrient loss reduction per dollar spent, relative to treating acres with lower inherent nutrient loss vulnerabilities. Importantly, this research raises considerations about use of models to guide land management decisions at very fine spatial scales. Decision makers using these results should be aware of data limitations that hinder fine-scale model interpretation.
\end{abstract}

Keywords: Lake Erie; NHDPlus model; Soft Data; Conservation Practice; SWAT-SAS; Model calibration 


\section{1. Introduction}

2 For the past two decades, complex watershed simulation models such as the Soil and Water

3 Assessment Tool (SWAT, Arnold et al., 2012), Agricultural Policy/Environmental eXtender

4 (APEX, Williams et al., 2012), and Hydrological Simulation Program-Fortran (HSPF, Bicknell

5 et al., 1997) have been implemented for water resources assessment. These and similar advanced

6 technologies enable modelers to investigate challenges associated with water supply, water

7 quality, pollutant control, and other ecosystem services (Chou and Wu, 2014; Jha and Gassman,

8 2014; Gebremariam et al., 2014). Model outputs are used to inform land management decision-

9 making and policy development at local to national scales (White et al., 2015a, b; Johnson et al., $102015)$.

11 As modeling technologies have been further refined to simulate more complex systems in

12 finer spatial and temporal resolution, parameter inputs required to calibrate the models have also

13 increased in complexity (Haan et al., 1995; Ajami et al., 2007). Model simulations of watershed

14 responses to various agricultural management scenarios in terms of hydrological, sediment, and

15 nutrient processes require a large number of physically/empirically based functions, but

16 monitoring efforts in agricultural systems that could provide those inputs are limited. To address

17 the challenges of providing sufficient input data and calibrating complex models (e.g., SWAT) at

18 a fine spatial scale of resolution, efficient optimization techniques and uncertainty analysis need

19 to be applied to ensure that statistically acceptable results are generated affordably and with

20 limited computational time (Duan et al., 1992; Tolson and Shoemaker, 2007; Vrugt et al., 2009;

21 Yen et al., 2014a). Because of the lack of monitored data to calibrate the model, assumptions are

22 often necessary during fine-scale model development. Caveats associated with these assumptions

23 should be given due consideration when interpreting modeled results. 
Although models have traditionally been calibrated with hard data, it is increasingly

25 necessary to use both hard and soft data to achieve model calibration. Non-temporal model

26 outputs and the associated predictive uncertainty that can be stated as aggregated indices of

27 watershed characteristics are considered soft data (Seibert and McDonnell, 2002). Soft data are

28 typically associated with intra-watershed processes, which have been demonstrated to impact

29 model predictions during model calibration (Yen et al., 2014b, c). It is possible to generate

30 model runs that perform well in terms of hard data outputs (model performance can be

31 tentatively categorized by statistical thresholds; Moriasi et al., 2007), but simultaneously produce

32 unreasonable soft data outputs (e.g. a simulated annual denitrification rate twice the rate of

33 measured data in the field; Yen et al., 2014b, c). Soft and hard data should both be carefully

34 considered to ensure that the calibrated model is appropriate for application in further analysis

35 (Efstratiadis and Koutsoyiannis, 2010).

36 Trade-offs in the relationship between model resolution and model performance (accuracy)

37 are of keen interest in the field of water resources analyses, because these models increasingly

38 serve as land management and policy development decision support tools (Chaubey et al., 2005).

39 This is particularly true in the Western Lake Erie Basin (WLEB), where nutrient management

40 strategies and water quality impacts have been a focus of modeling for decades (Di Toro et al.,

41 1973). Model calibration strategies have necessarily kept pace with model development,

42 enabling enhanced spatial and temporal resolution, so that model predictions are more relevant to

43 field-scale and local policy level decision-making processes (Cotter et al., 2003). However,

44 efforts related to widespread and long-term monitoring of water quality in WLEB have not kept

45 pace with model development. Robertson and Saad (2011) noted that the reduction in tributary

46 monitoring efforts in this region makes evaluation of current nutrient and sediment loadings 
47 difficult. Current monitoring data in the Lake Erie drainage basin is inadequate to measure

48 impacts of agricultural management on water quality (Betanzo et al., 2015) and thus insufficient

49 to support the scales at which models simulating these impacts are currently being applied. This

50 is one reason that the use of soft data is necessary for model calibration and one of the major

51 challenges to model validation.

52 The SWAT model continues to provide informative analyses at increasingly more refined

53 spatial scales. For example, the National Cropland reports published by the Conservation Effects

54 Assessment Project (CEAP) evaluate the impacts of agricultural management and conservation

55 practice adoption with the APEX (simulation under field scale level) and SWAT (combining

56 outputs from APEX and routing among subwatersheds) models, based on data valid at the 8-digit

57 Hydrologic Unit Code (HUC-8) scale of resolution for cropland in the contiguous USA (USDA-

58 NRCS, 2011; Johnson et al., 2015). The CEAP-Cropland reports inform conservation policy

59 decision making, including the Farm Bill's conservation spending budget. The USEPA (U.S.

60 Environmental Protection Agency) supported Hydrologic and Water Quality System (HAWQS)

61 is a user-friendly online system that applies SWAT to perform scenario analyses in multiple

62 resolution delineation formats, including the HUC-8, -10, and -12 digit scales (USEPA, 2015).

63 The NHDPlus dataset (National Hydrography Dataset) is the finest resolution watershed

64 boundary unit dataset currently available for large-scale modeling applications; the average size

65 of subwatersheds is $2.6 \mathrm{~km}^{2}$. There is only one large-scale watershed modeling implementation

66 of NHDPlus dataset reported to date. Daggupati et al. (2015) applied the SWAT model to

67 compare accuracy of simulation of hydrologic processes between HUC-12 and NHDPlus scales

68 in the Western Lake Erie Basin (WLEB). Building upon the work performed by Daggupati et al.

69 (2015), this study uses both hard and soft data (annual denitrification rate and nitrate $\left(\mathrm{NO}_{3}\right)$ loads 
70 contributed from tile drainage system) to develop SWAT models to describe sediment and

71 nutrient (total phosphorus and total nitrogen) dynamics at the NHDPlus scale in WLEB.

72 In 2002, the Farm Bill passed by the United States Congress included an $80 \%$ increase in

73 allocation of federal funds for agricultural conservation relative to the funding amount in the

74 previous Farm Bill (Johnson et al., 2015). CEAP was initiated by the USDA to conduct credible

75 scientific evaluation of the benefits derived from the increased use of federal financial resources

76 for agricultural conservation (Mausbach and Dedrick, 2004). A major goal of CEAP is to

77 quantify the impact of agricultural conservation practices on water quality (e.g. sediment,

78 nitrogen, phosphorus, and pesticide residues). The focused and scientifically credible outcomes

79 of these analyses can be used to help inform future conservation practice and program

80 investments, and may serve to guide conservation research inquiry and investments (White et al., 81 2014).

82 The impetus behind the development of this high resolution modeling project was a need

83 expressed by the Conservation Effects Assessment Project (CEAP) - Wildlife Component for a

84 product capable of accurate predictions of nutrient and sediment dynamics in the many very

85 small streams systems across WLEB in order to conduct aquatic stream health analyses. SWAT

86 model outputs developed from simulating the watershed at this scale could be used as data inputs

87 in biological models, such as those used to assess stream health and inform stream conservation

88 decisions (Keitzer et al., 2016). A principal caveat associated with this work is that while the

89 model may be capable of producing appropriately scaled and reasonable-seeming results,

90 insufficient quantitative data exist against which to compare the various model outputs at this

91 scale in order to determine whether the simulated spatial specificity is reflective of reality across 
92 the entire simulated WLEB. More monitoring is necessary in order to provide sufficient data for 93 complete model validation.

94 This implementation of the SWAT model in a sophisticated watershed analysis of WLEB at

95 the finest available, NHDPlus spatial resolution enhances both model performance and the 96 predictive capacity associated with cross-field investigations, enabling better modeling results in

97 the future. In considering the increasing interests in water quality issues in WLEB, this study 98 reports on a unique, novel, and timely application of the SWAT model, in which NHDPlus 99 resolution data are used to: (1) explore soft/hard data applications on NHDPlus scale model 100 development and subsequent predictions of streamflow, and sediment and nutrient dynamics 101 associated with agriculture in the WLEB; (2) demonstrate the utility of modeling at this scale to 102 describe the possible costs and benefits of various conservation practice adoption scenarios in the 103 WLEB. The most important reason that the NHDPlus stream network was adopted in this CEAP104 Wildlife study is because the fish community research associated with potential/current 105 contaminants requires detailed information such as simulated flow, sediment, and nutrients at the 106 stream reach scale. In addition, the approach conducted in this study that pairs conservation 107 scenarios with projected additional costs is particularly rare in literature, since that requires 108 mutual work among modelers (engineers), biologists, and economists. Spatially explicit 109 simulations like these provide important information to consider when managing agricultural 110 lands - knowledge gaps could be exposed that focused research efforts could help resolve. 


\section{2. Materials and Methods}

\section{$112 \quad 2.1 . \quad$ The SWAT Model}

113 The SWAT model was used to simulate streamflow and water quality in WLEB (Figure

114 1). SWAT is a process/empirical-based, quasi-distributed, continuous time-step model developed 115 by the United States Department of Agriculture - Agricultural Research Service (USDA-ARS) to 116 perform large-scale watershed simulations based on specified soil, landuse, weather, and 117 topographic data (Arnold et al., 2012). Potential impacts of current and changing land 118 management and conservation practice adoption on ecological goals and concerns can be 119 evaluated by simulating scenarios and analyzing predicted impacts on hydrologic, sediment, and 120 nutrients processes (Daggupati at al., 2011; Keitzer et al., 2016). SWAT is one of the most 121 broadly applied large-scale watershed simulation models in the field of water resource planning 122 and management (Gassman et al., 2007) and is among the toolsets used to inform conservation 123 practice policy within the USA (Johnson et al., 2015; Mausbach and Dedrick, 2005).

124 The publicly available version of SWAT is currently parameterized at three spatial scales:

125 (1) basin level; (2) subbasin level; and (3) HRU (Hydrologic Response Unit) level. HRUs are a 126 unique combination of slope, landuse, and soils; there can be many HRUs per subbasin whereas 127 parameters for a HRU can be very specialized by user discretion. The HRU level parameters are 128 specifically assigned to all HRU files so that the parameter values may be altered by the modeler 129 for selected HRUs. The subbasin level parameters are assigned uniformly within a given 130 subbasin, and the basin level parameters are uniformly applied to the entire basin defined by the 131 SWAT project. It was stated that SPCON (linear parameter to adjust sediment load in channel 132 sediment routing (Neitsch et al., 2011)) is one of the most sensitive parameters involved in 133 sediment and sediment-associated phosphorus calibration and calculating transportable 
134 maximum sediment load (Chu et al., 2004; White and Chaubey, 2005). However, SPCON is a

135 parameter specified at the basin level, so it is possible for SWAT simulations to over- or under-

136 estimate the basin sediment and sediment-associated phosphorus loads, especially because most

137 watersheds do not have homogeneously distributed topography (Neitsch et al., 2011). To

138 improve model predictions of sediment and sediment-associated phosphorus dynamics in this

139 study, a revised version of SWAT, named SWAT-SAS (Subregional Adjustment of Sediment)

140 was developed, which allows SWAT users to specify SPCON values for each subbasin within

141 the basin of interest. These subbasin specific adjustments in the *.rte files enhance the spatial

142 accuracy of sediment and sediment-associated phosphorus predictions. More details of SWAT-

143 SAS are described in Appendix A.

\section{2.2. Soft-Data-Constrained Calibration}

145 Large-scale watershed modeling efforts with sophisticated streamflow, sediment, and

146 nutrient dynamic simulation processes necessarily require the incorporation of a large number of

147 model parameters, some of which are difficult to populate with currently available datasets.

148 Various parameter estimation (or, calibration) techniques have been proposed to solve

149 challenging high-dimensional watershed calibration problems (Yen et al., 2014a). The parameter

150 estimation process (e.g., automatic or manual calibration) is designed to minimize the error term

151 between the observed and simulated data in a given time series (e.g., daily streamflow, monthly

152 sediment load). The temporal data used to calculate error statistics during calibration process can

153 be categorized as hard data (Seibert and McDonnell, 2002). Modelers can use manually defined

154 statistical guidelines, such as the General Performance Ratings (Table 2), to evaluate the

155 performance of error statistics (Moriasi et al., 2007). However, it was stated in literature that 
156 watershed simulation outputs may be inconsistent with real hydrological mechanisms and/or

157 intra-watershed processes (Yen et al., 2014b).

158 In addition to hard data in the form of temporal series, soft data are defined as non-temporal

159 measures of a watershed in reflecting intra-watershed processes such as denitrification, average

160 annual sediment loading, or ratio of nitrate attributed from subsurface versus surface flow (Yen

161 et al., 2016). Developing calibration routines without due consideration of soft data may produce

162 excellent model outputs in terms of error statistics, but the simulations may violate actual

163 watershed behavior. For example, in a case study at the Eagle Creek Watershed, Indiana, USA,

164 an auto-calibrated SWAT model without consideration of the region's prevalent tile drainage

165 system might provide accurate stream flow predictions, but would incorrectly attribute the

166 majority of flow to surface runoff losses (Yen et al., 2014b). The presence of the tile drainage

167 system requires the modeler to apply additional constraints to the model simulation rather than

168 relying on the auto-calibration system to correctly designate flow to the appropriate loss 169 pathways (Yen et al., 2014b).

170 In much of the Midwest region (MWR) of the USA, tile flow pathways contribute to 171 significant subsurface flow pathways; if model results are used to inform conservation practice 172 adoption decisions or conservation-related policy, overlooking the significance of this loss 173 pathway could lead to inappropriate land management decisions. In addition, the associated 174 predictive uncertainty may also be affected considerably (Yen et al., 2014c). It was indicated that 175 the use of soft data may have direct impact on both parameter and predictive uncertainty. Some 176 relevant parameters may not explore the full spectrum of given ranges because of the 177 incorporation of additional soft-data-constraints (however, exploration of uncertainty of hard/soft 178 data is not the primary goal in this study so it will not be fully investigated). In this study, soft- 
179 data-developed constraints were added to the denitrification rate and amount of nitrate $\left(\mathrm{NO}_{3}\right)$

180 contributed from tile flow to help govern the simulated intra-watershed processes in the region.

181 The denitrification rate is constrained to be less than $50 \mathrm{~kg} / \mathrm{ha}$ (David et al., 2009) and the ratio

182 of $\mathrm{NO}_{3}$ contributed by tile flow is constrained to be no less than two-thirds of total $\mathrm{NO}_{3}$ losses

183 (Schilling, 2002). For auto-calibration routines in practice, projected (or proposed) candidate

184 parameter sets are generated by the current best solution evaluated by statistical performance. By

185 the incorporate soft-data-constrained calibration, simulated results which violate the two

186 constraints are automatically rejected and will not be considered as the candidate parameter set.

187 In this case, the finalized calibration results will follow the constrained watershed behavior

188 automatically. The approach of soft-data-constrained calibration guarantees that quality of

189 derived model outputs to be representative to the real world in terms of better reflecting

190 hydrological and water quality processes. On the other hand, modelers and engineers can take

191 advantage of this approach to avoid the risk of generating good modeling results for the wrong

192 reasons.

$193 \quad$ 2.3. Study Area Description

194 The WLEB is located in the Midwestern United States of Ohio (76\%), Indiana (17\%) and

195 Michigan (7\%), has a drainage area of $23,817 \mathrm{~km}^{2}$, and is bounded by the Raisin River in the

196 north and the Sandusky River in the south (Figure 1). Elevation changes in the WLEB are fairly

197 mild (elevation varies from $246 \mathrm{~m}$ to $387 \mathrm{~m}$ above sea level), with an average slope of around

$1982 \%$. The mean winter temperature is $-5{ }^{\circ} \mathrm{C}$ and temperatures can rise to $29{ }^{\circ} \mathrm{C}$ in summer

199 (available from the National Oceanic and Atmospheric Administration (NOAA) Cooperative

200 Observer network and Weather- Bureau-Army-Navy stations). Average annual precipitation

201 ranges between 838 and $940 \mathrm{~mm}$. The major land use in WLEB is cultivated cropland (70\%), 
202 dominated by corn-soybean rotations; forest (12\%) and urban (12\%) lands comprise the other

203 dominant land uses in the region. A significant portion of the agricultural lands in WLEB, like

204 most agricultural lands across the MWR, are installed with well-organized tile drainage systems,

205 which enable agricultural activities (Kaatz, 1955) in a region previously dominated by a wetland

$206\left(4,000 \mathrm{~km}^{2}\right)$ called the Great Black Swamp (Mitsch et al., 2007). Although agricultural tile

207 drainage is used in other regions of the globe, such as Canada and Europe, the extensiveness and

208 level of sophistication of the MWR's large-scale agricultural tile drainage system is unique.

209 Model simulations of the impacts of various land management scenarios on conservation

210 concerns in this unconventional watershed must consider both natural and anthropogenic

211 influences on the mechanisms of surface and subsurface flow (groundwater, tile drainage flow)

212 in order to assess the actual watershed behavior.

\section{2.4. Model Setup/ Incorporation using NHDPlus Data}

214 Two SWAT models with different spatial resolutions were developed for the WLEB

215 region: (1) a HUC-12 scale model; and (2) an NHDPlus scale model, at the 30-meter Digital

216 Elevation Model (DEM) for topographical features (Figure 2). The HUC-12 model was built on

217 the Watershed Boundary Dataset (WBD) (1:24,000 scale-level) with 391 subbasins, which is

218 available online (http://datagateway.nrcs.usda.gov). The sizes of subbasins in the HUC-12 model

219 ranged from 25 to $191 \mathrm{~km}^{2}$ (average: $72 \mathrm{~km}^{2}$ ). The WBD dataset is conjointly synchronized by

220 the United States Geological Survey (USGS), United States Department of Agriculture - Natural

221 Resources Conservation Service (USDA-NRCS), and the United States Environmental

222 Protection Agency (USEPA). The NHDPlus dataset is coordinated by USGS and USEPA;

223 associated data (at 1:100,000 scale-level) is available online (http://www.horizon-systems.com/

224 NHDPlus/index.php). The NHDPlus model includes 11,128 subbasins, which range in size from 
2250.001 to $80 \mathrm{~km}^{2}$ (average: $2.6 \mathrm{~km}^{2}$ ). Daily streamflow calibrations in the NHDPlus version were 226 developed by Daggupati et al. (2015).

227 SWAT models were set up using the Geographic Information System (GIS) interface of 228 ArcSWAT2012 (rev593) (supported by ArcGIS10.1). Since it is time-consuming to execute a 229 SWAT project in NHDPlus resolution (e.g. 10 hours to complete a single 13-year SWAT run 230 using an Intel C Core $^{\mathrm{TM}}$ i5-2500k CPU @ $3.30 \mathrm{GHz}, 64$-bit operating system, Microsoft 231 Windows 7 Professional), a HUC-12 resolution SWAT model of WLEB was built and calibrated 232 for streamflow (each iteration consumes less than 2 hours for the same running period in 233 NHDPlus). The calibrated streamflow parameters were then transferred from the HUC-12 234 designed model to the NHDPlus project. Details can also be found in Daggupati et al. (2015).

235 Soils data were acquired from the publicly available USDA-NRCS State Soil Geographic 236 database for the Conterminous United States (STATSGO at 1:250,000 scale-level) (USDA237 NRCS, 1995). The simulated land uses were derived from the 30-meter resolution Crop Data 238 Layers (CDLs), which include major rotations of local crops (Srinivasan et al., 2010). The slope 239 information is incorporated with the soil and landuse data by HRU, where three slope categories $240(0 \sim 2 \%, 2 \sim 5 \%$, and $>5 \%)$ were defined, with the threshold area of 50 hectares for each. In 241 addition, row-crop agriculture was represented in HRUs without implementing pre-defined 242 thresholds. The total number of HRUs for the HUC-12 and the NHDPlus models was 13,156 and $243 \quad 34,807$, respectively.

244 Management practice data for agricultural activities were obtained from multiple sources.

245 Cropland tillage practices were available from USGS survey data (Baker, 2011). Operation 246 schedules designed for the RUSLE2.0 erosion model were acquired from USDA-ARS (Foster, 247 2005). Fertilization rates were obtained from National Agricultural Statistics Service (NASS) 
reports (USDA-NASS, 2014) of average crop yield at the county level. The assembled data were

249 organized in the format of SWAT management files by a software package in VB.net (code

250 available upon request). The management operations for agricultural activities (e.g., harvest/kill

251 operations) were defined by date, and heat units were applied to those without data. In SWAT

252 operation, historical precipitation was used for the years being simulated (e.g., from 1990 to

253 1999). On the other hand, it is very difficult to obtain the corresponding management details in

254 each and every year in practice. Therefore, the projected operation schedule was implemented to

255 reflect the management operation during simulation. Since spatial data on tile drainage systems

256 are not publicly available, it is not feasible to allocate tiles specifically to currently drained field

257 sites. Therefore, to accommodate for the impacts of tile drainage, the existence of tile drainage

258 was assumed on all agricultural soils with less than 1 percent slope and soils categorized as

259 poorly drained per the Soil Survey Geographic database

260 (http://www.nrcs.usda.gov/wps/portal/nrcs/detailfull/soils/ home). The HUC-12 and the

261 NHDPlus SWAT models use the same temperature and precipitation data (from 1960 to 2010)

262 inputs, available from the Weather Bureau Army Navy (WBAN) and Cooperative Observer

263 Network Stations collected by National Oceanic and Atmosphere Administration (NOAA).

264 Available measured streamflow, sediment, and water quality record data were used to

265 conduct model calibration (1990-1999) and validation (2000-2006) (Table 1). More details on

266 streamflow calibration in the NHDPlus scale model can be found in Daggupati et al. (2015).

267 Daily loads for total nitrogen, total phosphorus, and total suspended solids data used in

268 calibration and validation of nutrient and sediment processes were estimated from measured

269 USGS values with the Fluxmaster load estimation program (Schwarz et al., 2006; Robertson and

270 Saad, 2011) (Table 1). The LOAD ESTimator (LOADEST) program (Runkel et al., 2004) was 
271 used to estimate daily loads for soluble phosphorus and $\mathrm{NO}_{3}$ based on measurements of grab 272 samples taken at the gauging stations (Table 1).

\section{2.5. Model Calibration/Validation}

SWAT has been applied in WLEB at coarser scales than the analyses presented here,

275 including 350 subbasins and 4,416 HRUs in total; (Bosch et al., 2011 and 2013) and 4-digit

276 HUCs (USDA-NRCS, 2011). In this study SWAT simulated 391 subbasins and 13,156 HRUs at

277 HUC-12 scale; 11,128 subbasins and 34,807 HRUs at NHDPlus scale.

278 The potential impacts of nitrogen, phosphorus, and sediment loadings on aquatic species

279 can be evaluated through standardized indices such as IBI (Index of Biotic Integrity) and

280 dissolved oxygen in a given water body. Excess nitrogen and phosphorous concentrations in

281 freshwater can pose a serious threat to freshwater biodiversity and many of the valuable

282 ecosystem services provided by freshwater ecosystems (Carpenter et al., 1999, Smith et al.,

283 1999). For instance, nutrient loading from WLEB watersheds has contributed to eutrophication

284 of Lake Erie and threatens commercial and recreational fisheries, tourism, and the supply of safe

285 drinking water (Michalak et al., 2013, Kane et al., 2014). In the United States, nutrient

286 enrichment is a major contributor to degraded stream conditions (USEPA 2006). Water quality

287 (drinkability, fishability, swimability, etc.) issues in WLEB continue to concern municipalities

288 and the general public. In 2014, potentially 500,000 water users faced a drinking water crisis in

289 and around Toledo, Ohio, USA related to an algal bloom, a symptom of eutrophication (Dungjen

290 and Patch, 2014). This study provides scientific reference to nitrogen, phosphorus, and sediment

291 dynamics, which play a role in the development of harmful algal blooms (HABs) and toxicity of

292 the blooms. Although the drivers of HABs and their toxicity are poorly understood, they are

293 clearly an emerging threat to freshwater systems (Brooks et al., 2016.). This report and the 
294 SWAT model development associated with it may help inform land management and policy

295 decisions to help reduce the likelihood and/or frequency of recurrences of similar emergency

296 situations.

297 As mentioned earlier, SWAT streamflow calibration and validation in WLEB was 298 conducted in previous work (Daggupati et al., 2015). Weather data used for the calibration 299 period for the nutrients and sediment dynamics was from 1990 to 1999, with a three-year 300 additional simulation warm-up period (1987 to 1989); the validation was conducted on 2000 to 3012006 data. Since the NHDPlus project was computationally demanding, the sediment and 302 nutrients calibration of WLEB was conducted manually by expert judgement.

303 To evaluate the model performance under the developed calibrations, two quantitative error 304 statistics were used: the Nash-Sutcliffe Efficiency Coefficient (NSE) and the Percent Bias 305 (PBIAS). The NSE (Nash and Sutcliffe, 1970) has been implemented in a wide variety of 306 watershed modeling topics (Servat and Dezetter, 1991; ASCE, 1993) and has proven effective at 307 predicting reasonable temporal outputs, especially on seasonal peaks (Santhi et al., 2001). The 308 PBIAS statistical measure, on the other hand, performs better at capturing trends in consistent 309 watershed responses, such as average flow rate, which is important in maintaining stabilized fish 310 populations (USDA-NRCS, 2014). The potential magnitudes of NSE range from $-\infty$ to 1 . Perfect 311 matches between model predictions and observation data are indicated when NSE equals one. On 312 the other hand, the best PBIAS value is 0\%; underestimation is apparent when PBIAS $>0 \%$, and 313 overestimation is signified by PBIAS < $0 \%$. General performance ratings of NSE and PBIAS 314 values follow the convention developed by Moriasi et al. (2007) (Table 2). 


\section{2.6. Conservation Scenarios}

316 The CEAP-Croplands report on the Great Lakes region reports on conservation practices

317 and agricultural practices in use from 2003-06 (USDA-NRCS, 2011). The report classifies all

318 cropland acres into "needs classes" based on inherent vulnerabilities to leaching and or runoff

319 and levels of conservation treatment. In addition to analyses of "current conditions" simulations

320 and their impacts on conservation concerns, the CEAP-Croplands National reports contain

321 analyses on modeled hypothetical conservation scenarios that estimate potential impacts of

322 various conservation strategies associated with prioritizing treatment of acres according to

323 "needs classes" (USDA-NRCS, 2011). Simulation models were used to estimate potential

324 benefits and costs associated with applying prescribed conservation practices to any or all of the

325 classes of acres. Per the CEAP-Croplands classification conventions, "Critical Needs" acres have

326 a high need for additional conservation treatment; these acres include the most vulnerable of

327 under-treated acres, those with the fewest conservation practices in place, where the highest

328 losses of sediment and/or nutrients can be expected if no further conservation actions are taken.

329 "Moderate Needs" acres have an intermediate need for additional conservation treatment; these

330 acres are under-treated, but have lower inherent levels of vulnerability to losses or have some

331 effective conservation practices in place. "Low Needs" acres have low inherent vulnerabilities to

332 losses, or are adequately treated to address those vulnerabilities; these acres may still suffer

333 annual nutrient and sediment losses that could be lessened with additional treatment. Further,

334 current treatment levels on Low Needs acres must be maintained in order to ensure low nutrient

335 and sediment losses in the future.

336 One of the objectives is to demonstrate the potential outcomes of watershed modeling at

337 NHDPlus resolution by incorporating possible costs via different scenarios of conservation 
338 practices. Therefore, settings of parameters in each scenario are the same in order to conduct less

339 biased comparisons. The major differences in each scenario are the level of nutrient reduction by

340 alternated conservation practices applied (e.g., erosion control, nutrient management) and

341 resultant impacts on losses of nutrients and sediment from farm fields. The scenarios were

342 selected based on scenarios that CEAP-Croplands had applied in previous reports (USDA-

343 NRCS, 2014, 2015, and 2016). Using these scenarios broadens the potential implications of the

344 conducted analyses, as it allows for future comparison across regions that were similarly

345 simulated in CEAP-Croplands reports. In this study, eight simulations were performed with the

346 SWAT model developed for these analyses. The calibrated SWAT model represents the Baseline

347 condition (BL) and serves as the basis from which the other scenarios were developed. The

348 conditions observed in the BL scenario are the result of extensive conservation practices already

349 in use in the region. Every cultivated cropland acre in the WLEB region was treated with an

350 average of 1.8 conservation practices in 2003-06 and 2.4 conservation practices in 2012.

351 Conservation practices in place in WLEB in 2003-06 represented a \$208 million annual

352 investment ( $\$ 43.39$ per acre), whereas conservation practices in place in 2012 represented a $\$ 277$

353 million annual investment (\$56.98 per acre; USDA-NRCS, 2016). The data on practices and

354 management used to develop the BL were primarily from the time period between 2003-06 and 3552012.

356 Conservation treatment types were classified into two groups: erosion control practices 357 alone or erosion control practices in conjunction with nutrient management practices. Simulation 358 of six treatment scenarios explores the potential impacts of treating acres in particular needs 359 classes with one or both treatment practices at the watershed scale. Acres in each of the three 360 needs classes defined in the CEAP-Croplands report on the Great Lakes (NRCS-2011) were 
361 treated with either structural practices or both structural and nutrient management practices 362 (Table 3).

363 An additional Grass Background (GBG) scenario was simulated to provide context for the 364 predicted impacts of "current" agricultural management. The GBG scenario provides an estimate 365 of sediment and nutrient losses in the absence of agriculture (replaced by grass cover). The eight 366 simulated scenarios were analyzed to provide estimations of annual financial costs and 367 conservation impacts of various watershed-scale conservation strategies (Table 3 and Figure 4).

368 The primary conservation practice cost data source was the 2010 official state USDA-NRCS 369 Payment Schedule database, augmented with cropland rental rates, commodity prices, and 370 fertilizer prices from other published sources (USDA-NRCS, 2012). The NRCS National 371 Conservation Plans (NCP) database was used to estimate the average number of units of practice 372 per protected acre by state and practice. Rates from the NRCS Technical Service Provider 373 database were used as a proxy for Technical Assistance (TA) costs. Since a farm field may have 374 a variety of practices applied, each with a different useful life span, a special Equivalent Net 375 Annual Value formula was used to amortize the cost of each practice, sum the costs across 376 practices for each sample point, and calculate the annualized cost per acre of the treatment 377 alternative (Boardman, et al., 2001). The costs used here include the full cost of planning, 378 installation, maintenance, and forgone income on land converted to conservation cover, 379 regardless of whether some or all of the cost would be partially reimbursed to the farmer or 380 incurred by a non-farm entity such as a federal agency. State average cropland rental rates were 381 used as the cost of land converted from active crop production to a conserving use such as filter 382 strips or buffers (USDA-NASS, 2011). All conservation practice costs were converted to units of 383 practice per protected acre, using data from the NCP database. For example, the NCP data may 
384 show that on average 1.6 acres of buffer strip are used per 40 acres of cropland field, for a ratio

385 of 0.04 acres of buffer practice per acre of protected cropland. If the buffer strip annualized cost

386 per acre of buffer was $\$ 100$, then for this example, the modeled cost would be $\$ 4$ per protected

387 acre $(\$ 100 * 0.04)$.

388 2.7. Potential Biological Applications

389 The potential for conservation practices to improve stream biological conditions was 390 explored by quantifying the amount of streams potentially degraded by excess nutrients in each

391 conservation scenario. Excess nutrients are a pervasive threat to stream biodiversity (Richter et

392 al., 1997; Dudgeon et al., 2006; Vörösmarty et al., 2010). For example, recent surveys suggest

393 that excess nutrients are potentially degrading stream biological conditions in $>40 \%$ of the rivers

394 and streams in the United States (United States EPA, 2016). For the purposes of this study, a

395 stream segment was classified as degraded if average annual total nitrogen (TN) or total

396 phosphorus (TP) concentrations were above established nutrient criteria shown to increase

397 primary production excessively and alter stream algae, aquatic insect, and fish communities

398 (Evans-White et al., 2013). A stream segment's average concentration was calculated as the

399 mean of median annual concentrations from the 21-year simulation for each conservation

400 scenario. Outcomes for each conservation scenario were compared to the baseline scenario to 401 assess the benefits provided by that scenario.

402 A number of nutrient criteria have been developed to assess stream health and while there is 403 some agreement in the general magnitude of threshold values, the actual thresholds can vary by 404 more than 6-fold (Evans-White et al., 2013). Nutrient criteria are particularly influenced by the 405 statistical method (e.g., percentile approaches, 2DKS, regression tree), location (e.g., ecoregion), 406 and biological response (e.g., algae, aquatic insects, or fish) used in their development (Evans- 
407 White et al., 2013). To account for this variability explicitly, 43 different nutrient criteria from a 408 recent review of stream nutrient criteria in the United States (Table 4 in Evans-White et al., 409 2013) were used to assess potential stream degradation. These nutrient criteria included 410 thresholds for both $\mathrm{TN}$ and TP based on empirical observations and were developed using a 411 variety of statistical methods and biological responses (Evans-White et al., 2013).

412 A linear mixed model was used to assess the return on investment of different conservation 413 practice types (erosion control only vs. erosion control and nutrient management). This model 414 included the different nutrient criteria as random intercepts, and the additional cost of a 415 conservation scenario, practice types included in a conservation scenario, and their interaction as 416 fixed effects. The model used was:

$$
\begin{gathered}
y_{i}=\alpha_{j(i)}+\beta_{1} X_{i 1}+\beta_{2} X_{i 2}+\beta_{3} X_{i 3}+\epsilon_{i} \\
\alpha_{j} \sim N\left(\mu_{\alpha}, \sigma_{\alpha}^{2}\right)
\end{gathered}
$$

417 where in the first level of the model $y_{i}$ is the percent of the watershed improved in conservation 418 scenario $i$ using nutrient criteria $j$ as a function of practice types included $X_{1}$, the amount of 419 additional investment $X_{2}$, and their interaction $X_{3}$. In the second level of the model, nutrient 420 criterion $\alpha_{j}$ was normally distributed with a mean of $\mu_{\alpha}$ and residual variance of $\sigma_{\alpha}^{2}$ across all 421 nutrient criteria. The effects of cost, practice types included, and their interactions were 422 considered significant if the bootstrapped $95 \%$ confidence intervals of the estimates did not 423 include zero (replicates $=10,000$ ). All models were fit using the lme4 package (Bates et al., 424 2014) in the R statistical environment (R Core Team 2014). 


\section{3.1. Results of Calibration/Validation}

427 As it was stated previously that watershed simulation of the NHDPlus project is an 428 extremely time-consuming task. Therefore, a HUC-12 model was initiated and calibrated for 429 streamflow in advance of the development of the NHDPlus scale model (Daggupati et al., 2015).

430 One of the most important conclusions was made by Daggupati et al. (2015) was that some 431 subbasins are similar to other adjacent ones in terms of geographical differences and also 432 modeling behavior. Therefore, a total of five major subregions were categorized to conduct the 433 following computationally expensive NHDPlus project. Five representative gauge stations 434 (Daggupati et al., 2015) selected for watershed calibration and validation are shown in Figure 1 435 and Table 4. According to the General Performance Ratings (Table 2), the daily streamflow 436 calibration and validation can be considered between "Satisfactory" and "Good" (calibration: 437 NSE: $0.54 \sim 0.87$; PBIAS (\%): -11.76 22.70; validation: NSE: $0.43 \sim 0.88$; PBIAS (\%): -26.07 438 25.25). In general, higher statistical standards are expected for streamflow calibration since 439 flow is the fundamental medium of hydrologic, sediment, and nutrient processes in watersheds. 440 However, streamflow calibration could be compensated for by sediment and nutrient 441 mechanisms, especially in the NHDPlus resolution. It is extremely difficult to achieve "Very 442 Good" simulation of streamflow processes while concurrently calibrating for other output 443 variables to be within appropriate ranges in terms of statistical performance.

444 Statistical metrics for monthly sediment calibration and validation ranged from "Good" to 445 "Very Good" (calibration: PBIAS (\%): -10.43 18.63); validation: PBIAS (\%): -35.01 35.46) 446 It is important to have sediment processes well-calibrated because of the interaction between 447 sediment and total phosphorus dynamics, due to sediment-associated phosphorus. Results for 
448 monthly total phosphorus calibration and validation were "Very Good" (calibration: PBIAS (\%):

$449-12.78 \sim 8.42$; validation: (PBIAS (\%): $0.61 \sim-22.74$ ). Model predictions for monthly total

450 nitrogen ranged from "Satisfactory" (validation at St. Joseph) to "Very Good" (all other 451 stations).

452 Model performance varied between individual gauging stations. The model provided better 453 performance for the Maumee River gauge ("Very Good" results in all output variables) 454 compared to the other stations (temporal results of streamflow, sediment, and nutrients are 455 shown in Figure 3). Among the five selected gauge stations, the Maumee River Station is the 456 most representative outlet, since it receives $68.3 \%$ of the whole drainage area. In addition to hard 457 data calibration, soft data used in these analyses, can have substantial impact on model 458 predictions (Seibert and McDonnell, 2002; Yen et al., 2014b). The biological analyses in this 459 study required simulation results which mimic realistic watershed responses. To simulate actual 460 watershed behavior correctly, denitrification rate (DENI) and $\mathrm{NO}_{3}$ contributed from tile flow 461 (SSQ_Ratio) were constrained within certain ranges (DENI $\leq 50 \mathrm{~kg} / \mathrm{ha}$; SSQ_Ratio $\geq 0.6$ ). The 462 calibrated SWAT model had a DENI of $23.31 \mathrm{~kg} / \mathrm{ha}$ and SSQ_Ratio of $0.72\left(72 \%\right.$ of $\mathrm{NO}_{3}$ 463 attributed to subsurface flow pathways) and both soft data outputs were reasonable (in quantity 464 and in ratio) according to the available literature (Schilling, 2002; David et al., 2009).

465 As mentioned previously, the NHDPlus SWAT simulation of WLEB is exceptionally 466 computationally expensive. It is not feasible to conduct thousands of model simulations during 467 parameter estimation. Instead, expert judgement was used, especially for sediment and nutrient 468 calibration. Therefore, necessary compensation (trade-off) has been made during the calibration 469 process. 


\subsection{Applications of Conservation Scenarios}

471 The conservation strategies simulated here explore potential conservation gains and 472 associated financial costs that may be expected from the application of various suites of practices

473 to various acres (Figure 4, Table 3). The application of structural practices that provide erosion 474 control without complementary nutrient management practices (ECC, ECA, and FT; Table 3) is 475 much less expensive than is inclusion of structural practices and nutrient management. 476 Application of structural practices on Critical Needs, All Needed, or all cropland acres, (ECC, 477 ECA, and FT scenarios) could be implemented at 54, 37, and 49 percent of the respective costs 478 required to supplement structural practices with nutrient management practices on these same 479 acres (NMC, NMA, and NM, respectively).

480 The NM scenario suggests adoption of erosion control and nutrient management on all 481 cropland acres could reduce annual loads of sediment being lost from croplands by up to 45 482 percent, total nitrogen by up to 41 percent, nitrate nitrogen by up to 32 percent, total phosphorus 483 by up to 54 percent, and dissolved phosphorus by up to 28 percent (Figure 4), but adoption of 484 NM does not alleviate all of the sediment, nitrogen, or phosphorus conservation concerns in all 485 of the streams. Even simulated elimination of agriculture from the landscape and simulated 486 conversion all agricultural lands to vegetated easements (GBG scenario) did not reduce any 487 nutrient or sediment losses by more than 80 percent, suggesting that other land uses currently 488 contribute to sediment and nutrient loads (Figure 4). Restoring stream health across the region 489 will likely require efforts from all stakeholders and not just the agricultural community.

490 Maintaining current conservation and applying nutrient and structural erosion treatment to 491 all agricultural acres in WLEB would cost around half a billion dollars every year. These funds 492 are not currently available; therefore, the idea of prioritizing conservation spending by targeting 
493 Critical Needs acres for treatment before all other acres has been posited. However, an important

494 and interesting finding of this work is that treating acres classified as Low Needs provides 495 substantial benefits in almost all cases, relative to treating only Critical Needs or Critical and

496 Moderate Needs acres. These simulations suggest that an effective conservation strategy for 497 cropland acres in WLEB should consider implementation of improved conservation practices on 498 all cropland acres in the region, including those that have a low inherent vulnerability to losses 499 and those that are already well treated.

500 It should be noted that the conservation scenarios explored here were developed to reduce 501 edge-of-field losses, not to meet the needs of the streams or the ultimate receiving water body, 502 Lake Erie. Further, these scenarios were not developed to represent the most cost effective 503 policies to reduce nutrient and sediment loads to the streams or to Lake Erie. Land managers and 504 communities must identify their conservation goals and develop comprehensive plans to achieve 505 those goals; these plans will likely include both on-field and off-field conservation practices.

506 As expected, targeting treatment to critical needs acres provides the largest conservation 507 return per dollar investment. Critical Needs acres can be treated with erosion control (ECC) at 4 508 percent of the investment required to treat all acres with erosion control (FT) and provides 13 509 percent of FT's annual sediment conservation benefits. All Needed acres can be treated with 510 erosion control (ECA) at 43 percent of the cost of FT and will provide 56 percent of FT's annual 511 sediment loads reduction benefits. Therefore, although low needs acres have the potential to 512 provide nearly half of all possible sediment reduction benefits, there is a higher cost per unit of 513 sediment reduction benefit on these acres than on Critical Needs and Moderate Needs acres.

514 Estimations of the annual reductions in sediment loads lost from agricultural acres in WLEB 515 under alternative scenarios are shown in Figure 4(A). As would be expected, structural erosion 
516 control practices have a significant impact on reduction of sediment loads. Increasing treatment

517 to include nutrient management practices drastically increases the cost of treatment, but provides

518 no benefit to sediment loss reductions (Table 3, Figure 4). For example, all acres can be treated

519 with erosion control practices (FT) at 49 percent of the cost of treating all acres with erosion

520 control and nutrient management (NM), but both options reduce sediment loads being lost from

521 agricultural acres by 45 percent, relative to baseline conditions.

522 Estimations of the annual reductions in total nitrogen loads being lost from agricultural acres

523 in WLEB under alternative scenarios are shown in Figure 4(B). Inclusion of nutrient

524 management with structural erosion control practices had a much greater impact on total nitrogen

525 loss reduction than did structural practice adoption alone. The simulated benefits of enhanced

526 nutrient management practices on annual nitrate reductions are dramatic, likely due to the fact

527 that erosion control practices only address overland flow losses and nitrate may be lost to

528 subsurface flow pathways (Figure 4D). The application of structural practices to control erosion

529 (ECC, ECA, and FT) achieves only 56, 51, and 59 percent of the potential annual total nitrogen

530 load reduction benefits achieved in scenarios that apply structural practices and nutrient

531 management practices (NMC, NMA, and NM) on Critical Needs, All Needed, or all cropland

532 acres, respectively (Figure 4B). However, ECC, ECA, and FT provide only 15, 5, and 4 percent

533 of the nitrate load reduction benefits achieved in the NMC, NMA, and NM scenarios,

534 respectively (Figure 4D). Treating all acres with erosion control practices (FT; $\$ 128.3$ million,

535 annually) provides over three times the annual benefits in total nitrogen load reduction, but

536 provides only 19 percent of the nitrate loss benefits relative to gains made with adoption of

537 erosion control and nutrient management on Critical Needs acres only (NMC; \$8.4 million,

538 annually). Thus, nutrient management is clearly necessary if nitrate load reductions are the 
539 principal conservation goal. Investment decisions should carefully consider the resource concern

540 of interest, as different management strategies are required to meet various conservation goals.

541 Estimations of the annual reductions in total phosphorus loads being lost from agricultural

542 acres under alternative scenarios are shown in Figure 4(C). Phosphorus, unlike nitrogen, is

543 commonly bound to sediment. Therefore, erosion control practices tend to have more impact on

544 total phosphorus losses than on total nitrogen losses. However, application of nutrient

545 management in conjunction with structural erosion control practices has a much greater impact

546 on total phosphorus loss reduction than does structural practice adoption alone. This effect is

547 markedly more dramatic when impacts on annual dissolved phosphorus load reductions are

548 considered, likely due to the fact that erosion control practices only address overland flow losses,

549 whereas dissolved phosphorus may also be lost to subsurface flow pathways (Figure 4E).

550 The application of structural practices to control erosion (ECC, ECA, and FT) achieves 93,

55183 , and 84 percent of the annual total phosphorus load reduction benefits achieved in scenarios

552 that apply structural practices in conjunction with nutrient management practices (NMC, NMA,

553 and NM), respectively (Figure 4C). However, ECC, ECA, and FT provide only 62, 23, and 22

554 percent of the potential dissolved phosphorus load reduction benefits that could be achieved with

555 inclusion of nutrient management alongside erosion control (in NMC, NMA, and NM,

556 respectively (Figure 4E)). This suggests that on Critical Needs acres a significant amount of the

557 dissolved phosphorus being lost could be conserved through structural practice adoption,

558 whereas on the moderate and low needs acres nutrient management practices are imperative in

559 order to achieve comparable reductions in dissolved phosphorus losses. Model simulations

560 suggest that treatment of all acres with structural erosion control practices (FT; $\$ 128.3$ million,

561 annually) provides over 4.8 times the annual benefits in total phosphorus load reduction, but 
562 provides only 1.3 times the dissolved phosphorus loss benefits relative to gains that could be

563 made with adoption of structural erosion control and nutrient management practices on Critical

564 Needs acres only (NMC; \$8.4 million, annually). As with nitrogen management decisions,

565 phosphorus management strategies must take into account the importance of treating for total

566 phosphorus reduction or targeting dissolved phosphorus reduction. The conservation goal

567 informs the appropriate conservation strategy.

568 Beyond the general comparisons for each output variable, cross comparisons between total

569 nitrogen and total phosphorus are also interesting. WLEB and most of the MWR are heavily

570 tiled, so that most excess precipitation is transported through tile drainage systems. Rerouting

571 water through tiles also reroutes nutrients to subsurface pathways. Tile drains are not only loss

572 pathways for nitrate nitrogen and dissolved phosphorus, but have also been implicated as a loss

573 pathway for sediment and sediment-associated phosphorus losses (Gaynord and Findlay, 1995;

574 Molder et al., 2015). These results suggest that careful and comprehensive conservation planning

575 that provides nutrient loss reductions in all loss pathways is needed to provide desired nitrogen

576 and phosphorus loss reductions in this unique area (Figures 4B and 4C).

\section{$577 \quad 3.3 . \quad$ Model Responses Enclosed in Stream Order Levels}

578 To examine additional information that can be obtained from the NHDPlus resolution

579 SWAT model, model responses for spring and summer seasons by different stream order were

580 examined (Figures 5 and 6). Larger loads are predicted during spring as compared to summer,

581 which is consistent with regional weather. Greater flows are expected in WLEB during spring,

582 when snow melt occurs. Snow melt and spring rains may mobilize nutrients applied during

583 spring planting or in the previous fall. 
Modeling at this scale exposed the fact that rivers with lower stream orders have a higher

585 degree of uncertainty. There are multiple reasons for this uncertainty. One reason is that

586 calibration at this scale is difficult due to lack of calibration data; there is uncertainty associated

587 with spatial interpretations when data are lacking. Low stream order streams and rivers are

588 generally smaller in size, so may be less resilient to disturbance, such as flooding events and or

589 anthropogenic disturbances. Therefore, simulated nutrient and sediment quantities in low order

590 streams may vary substantially from reality, which estimates in higher order streams should be

591 better calibrated and have less uncertainty.

592 Because of lower order stream vulnerabilities to perturbation, conservation practices that

593 benefit lower order streams are likely to be beneficial to stream health in the region. These lower

594 order streams feed into higher order streams, which would then also benefit from the

595 conservation practices that reduced loads to the lower order streams. The biological indicators

596 used in this work suggest that increased focus should be placed on conservation practices that

597 target loss reduction in the spring season instead of the entire year (Keitzer et al., 2016).

\section{$598 \quad 3.4 . \quad$ Potential Reductions in Degraded Biological Conditions}

599 Anthropogenic disturbance, including nutrient enrichment is a serious threat to stream

600 biodiversity (Richter et al., 1997; Dudgeon et al., 2006; Vörösmarty et al., 2010). Nutrient

601 enrichment can cause excessive algal growth, alter algal community structure and food quality,

602 and decrease dissolved oxygen levels, all of which can degrade stream biodiversity (Miltner and

603 Rankin 1998, Dodds et al., 2006, Wang et al., 2007, Evans-White et al., 2009, Miltner 2010,

604 Taylor et al., 2014). Understanding the effectiveness of conservation actions on mitigating

605 nutrient enrichment of streams and rivers at the watershed-scale is therefore a key component of 606 effective stream biodiversity conservation. 
Averaged across all nutrient criteria, we estimate that $95 \%$ of WLEB streams have some

608 level of nutrient enrichment that could degrade habitat and decrease biodiversity (about 19,256

$609 \mathrm{~km}$ of streams). This includes nearly $73 \%$ of the streams in the watershed estimated to have

610 annual nutrient levels above TP criteria, 93\% above TN criteria, and nearly $68 \%$ of stream

611 segments have both TP and TN concentrations above the nutrient criteria used for this study.

612 These estimates suggest that while both are widespread in WLEB streams, streams are more

613 likely to have excess nitrogen concentrations than excess phosphorus concentrations. However,

614 high levels of both nutrients co-occur across a substantial portion of the watershed. Nutrient

615 management strategies likely need to address both nitrogen and phosphorus losses through all

616 potential loss pathways to be effective at providing benefits to stream biodiversity and health.

617 Our results suggest that the conservation practices simulated here are more effective at 618 reducing stream degradation as the result of excess phosphorus than nitrogen (Fig. 7). We found

619 that across all nutrient criteria and conservation scenarios, the percent of streams with improved 620 water quality associated with scenario adoption ranged from $<1 \%$ to $34 \%$ based on TP criteria 621 and from $<1 \%$ to $12 \%$ for TN criteria. Regardless of whether one or both nutrients are selected 622 as the dominant conservation concern in the region, achieving large reductions will likely require 623 treating a substantial portion of the watershed. For instance, treating only Critical Needs acres 624 with erosion control and nutrient management provides at most a 3\% reduction in the percent of 625 streams impacted by phosphorus; treating all agricultural acres in the region with structural 626 controls and nutrient management can provide up to a $34 \%$ reduction in streams impacted by 627 phosphorus. Similar results from a variety of watersheds suggest that conservation practices must 628 be widely implemented to achieve the large reductions in nutrient and sediment losses from 
629 agricultural lands needed to improve stream biodiversity throughout the watershed (Einheuser et 630 al., 2012, Bosch et al., 2013).

631 Our results also suggest that there are differences in potential return on investment of 632 depending on the conservation concern being addressed (Table 5, Fig. 7). Erosion control 633 practices alone represent a more cost effective strategy for reducing degradation by TP, while 634 including nutrient management proves to be a more cost effective means for reducing 635 degradation by TN (Table 5, Fig. 7). Because both nitrogen and phosphorus can negatively affect 636 stream biodiversity (Miltner and Rankin 1998; Wang et al.. 2007; Evans-White et al.. 2009), it is 637 likely necessary that both must be managed appropriately if stream biodiversity is to be restored 638 across the watershed. This effort will require development of comprehensive conservation plans 639 and investments in both structural erosion control and nutrient management.

640 This work only considered the benefits of conservation investments on in-field and edge-of641 field practices as they relate to nutrient losses. However, conservation practices can also reduce 642 sediment loading to streams, reduce the frequency of extreme flows (e.g., stream drying), and 643 improve in-stream habitat, all of which should benefit stream biodiversity (Wang et al., 2002, 644 Wang et al., 2006). We may therefore have underestimated the potential benefits of in-field and 645 edge-of-field conservation practices, particularly if multiple stressors interact to affect stream 646 biodiversity, which appears to be common (Townsend et al., 2008, Matthaei et al., 2010, 647 Wagenhoff et al., 2011, Wagenhoff et al., 2012). In-stream practices were not explored here and 648 may be valuable complements to on-farm conservation practices.

649 While nutrient enrichment is a pervasive threat to stream biodiversity (Richter et al., 1997; 650 Dudgeon et al., 2006; Vörösmarty et al., 2010; US EPA 2015; US EPA 2016), it should be noted 651 that it is not the only factor contributing to habitat degradation in the region. Among other 
652 stressors (e.g., invasive species), changes to in-stream habitat quality (e.g., siltation), flow

653 regimes, and riparian vegetation are also prevalent concerns in the WLEB (Trautman 1939,

654 Trautman and Gartman 1974, Karr et al., 1985). Conservation practices simulated here are

655 limited to in-field and edge-of-field practices and their impacts on overland and subsurface water

656 flows and associated nutrients. Other stream restoration techniques, including in-stream

657 practices, dam removal, road improvements, riparian restoration, improved floodplains

658 connectivity, etc., were not considered here and may be essential to successful holistic

659 agroecosystem planning and stream habitat improvement at the watershed scale. Results

660 presented here should be considered with the caveat that the stressors and practices explored are

661 limited in scope; these scenarios may under or overestimate the potential benefits of conservation

662 practices in conjunction with other management across the landscape.

663

\section{4. Conclusion}

665 In this study, SWAT was applied at the NHDPlus resolution to explore the model's capacity

666 to estimate potential environmental impacts of alternative conservation practices in terms of

667 sediment and nutrient losses reduction with corresponding projected cost. An important finding

668 is that SWAT is able to parse the varied impacts of conservation practices on total nitrogen, total

669 phosphorus, nitrate, and dissolved phosphorus in response to the same conservation practice.

670 However, without adequate monitored data, the fine-scale results cannot be appropriately

671 validated. This work improves SWAT's capacity to serve as a decision support tool to determine

672 conservation strategies associated with various conservation concerns and nutrient loss

673 pathways. Structural erosion practices alone provide a sufficient remedy to sediment loss and

674 could reduce current sediment loads lost from agricultural acres by up to 45 percent. The model 
675 also demonstrated that nutrient loss reduction strategies, especially for nitrate and dissolved

676 phosphorus, benefit from the inclusion of nutrient management plans. In the WLEB, dissolved

677 phosphorus is a critical concern (Daloglu et al., 2012; Baker et al., 2014). Therefore, realistically

678 predicting dynamic responses to management can be valuable to researchers from various

679 disciplines, as well as land use planners.

680 The work presented here is not just another piece of a calibration/validation project in

681 watershed modeling. Instead, it is the first time in history that the most advanced technology of

682 delineating stream networks at the fine resolution (NHDPlus) was implemented on a large-scale

683 watershed like the WLEB. The goal of this study was to determine if the SWAT model was

684 capable of identifying environmental impacts caused by agricultural activities, including various

685 conservation strategies, at a refined spatial scale by applying the state-of-the-art techniques,

686 including soft-data calibration. The model proved capable to simulating seemingly reasonable

687 statistical results. While this manuscript and the model developed to support it provide scientists,

688 engineers, and stakeholders with increased science-based information to augment current

689 decision support tools for determining appropriate land management and policy development, it

690 should be noted that there is insufficient spatially explicit monitoring data in the region to

691 support appropriate validation of the model's spatially explicit results. It is true that the proposed

692 finest resolution model may produce uncertainty and artificial errors because of the limitation.

693 However, potential errors could cause more negative impacts on model predictions if the

694 associated biological analysis was conducted in larger scale such as HUC-12 (average $72 \mathrm{~km}^{2}$ in

695 unit size which is more than 27 times larger than average unit area of NHDPlus).

696 Implementations of finer resolution data are not only to scale down the individual unit of 
simulation, but it also can provide more information as indications that particular issues needed

to improve in the future to enhance the accuracy of the modeling work.

\section{References}

Ajami, N. K., Duan, Q., and Sorooshian, S., 2007. An integrated hydrologic Bayesian multimodel combination framework: Confronting input, parameter, and model structural uncertainty in hydrologic prediction, Water Resources Research, 43(1), 1-19.

Arnold, J., Moriasi, D., Gassman, P., Abbaspour, K., White, M., Srinivasan, Santhi, C., Harmel, R.D., van Griensven A., Van Liew M.W., Kannan N., and Jha, M. K., 2012. SWAT: Model use, calibration, and validation. Transactions of the ASABE, 55(4), 1491-1508.

Arnold, J. G., Allen, P. M., Bernhardt, G., 1993. A comprehensive surface-groundwater flow model, Journal of Hydrology, 142, 47-69.

ASCE, 1993.Criteria for evaluation of watershed models, ASCE task committeeon definition of criteria for evaluation of watershed models of the watershed management, irrigation, anddrainagedivision.J.Irrig.Drain.Eng.119,429.

Baker, D. B., R. Confesor, D. E. Ewing, L. T. Johnson, J. W. Kramer, and B. J. Merryfield. 2014. Phosphorus loading to Lake Erie from the Maumee, Sandusky, and Cuyahoga rivers: the importance of bioavailability. Journal of Great Lakes Research 40:502-517.

Baker, N.T., 2011. Tillage practices in the conterminous United States, 1989-2004-Datasets Aggregated by Watershed: U.S. Geological Survey Data Series 573.

Betanzo, E. A., Choquette, A. F., Reckhow, K. H., Hayes, L., Hagen, E. R., Argue, D. M., and Cangelosi, A. A. 2015. Water data to answer urgetn water policy questions: monitoring design, available data and filling data gaps for determining the effectiveness of agricultural management practices for reducing tributary nutrient loads to Lake Erie, Northeast-Midwest Institute Report, 169 p. http://www.nemw.org?.

Bicknell, B. R., Imhoff, J. C., Kittle, Jr. JL., Donigian, A. S., Johanson, R. C., 1997. Hydrological Simulation Program--Fortran: User's manual for version 11. U.S. Environmental Protection Agency, National Exposure Research Laboratory, Athens, GA, EPA/600/R-97/080. 755 p.

Blann, K. L., J. L. Anderson, G. R. Sands, and B. Vondracek. 2009. Effects of Agricultural Drainage on aquatic systems. Critical Reviews in Env. Sci. Tech. 39:909-1001.

Boardman, A. E., D. H., Greenberg, A. R. Vining, and D. L. Weimer, 2001. Cost-Benefit Analysis. Concepts and Practice, 2nd Edition. Prentice Hall, Upper Saddle River, NJ.

Bosch, N.S., Allan, J.D., Dolan, D.M., Han, H., Richards, R.P., 2011. Application of the Soil and Water Assessment Tool for six watersheds of Lake Erie: Model parameterization and calibration. J. Great Lakes Res. 37, 263-271.

Bosch, N.S., Allan, J.D., Selegean, J. P., Scavia, D., 2013. Scenario-testing of agricultural best management practices in Lake Erie watersheds. J. Great Lakes Res. 39, 429-436.

Brooks, B., Lazorchak, J.M., Howard, M.D.A., Johnson, M-V.V., Morton S.L., Perkins, D.A.K., Reavie, E.D., Scott, G.I., Smith, S.A., and Steevens, J.A.. 2016. Are harmful algal blooms becoming the greatest inland water quality threat to public health and aquatic systems? Environmental Toxicology and Chemistry 35, 6-13. 
Carpenter, S.R., Caraco, N.F., Correll, D.L., Howarth, R.W., Sharpley, A.N., Smith, V.H., 1998. Applications, 8, 559-568.

Chaubey, I., Cotter, A. S., Costello, T. A. and Soerens, T. S., 2005. Effect of DEM data resolution on SWAT output uncertainty. Hydrol. Process., 19, 621-628. doi: 10.1002/hyp.5607

Chu, T. W., Shirmohammadi, A., Montas, H., Sadeghi, A., 2004. Evaluation of the SWAT Model's sediment and nutrient components in the piedmont physiographic region of Maryland. Transactions of the Asabe 47(5), 1523-1538

Chou, F. N.-F. and Wu, C.-W., 2014. Determination of cost coefficients of a priority-based water allocation linear programming model - a network flow approach, Hydrol. Earth Syst. Sci., 18, 1857-1872, doi:10.5194/hess-18-1857-2014

Cotter, A. S., Chaubey, I., Costello, T. A., Soerens, T. S. and Nelson, M. A., 2003. Water quality model output uncertainty as affected by spatial resolution of input data. JAWRA Journal of the American Water Resources Association, 39: 977-986. doi: 10.1111/j.17521688.2003.tb04420.x

Daggupati, P., Douglas-Mankin, K.R., Sheshukov, A.Y., Barnes, P.L., Devlin, D.L., 2011. Fieldlevel targeting using SWAT: Mapping output from HRUs to fields and assessing limitations of GIS input data. Transactions of the Asabe 54, 501-514.

Daggupati, P., Yen, H., White, M. J., Srinivasan, R., Arnold, J. G., Keitzer, C. S., and Sowa, S. P., 2015. Impact of model development, calibration and validation decisions on hydrological simulations in West Lake Erie Basin. Hydrol. Process., doi: 10.1002/hyp. 10536.

Daloglu, I., K. H.Cho, and D. Scavia. 2012. Evaluating causes of trends in long-term dissolved reactive phosphorus loads to Lake Erie. Env. Sci. Tech. 46: 10660-10666.

David, M.B., S.J. Del Grosso, X. Hu, E.P. Marshall, G.F. McIsaac, W.J. Parton, C. Tonitto, and M. Youssef. 2009. Modeling denitrification in a tile-drained, corn and soybean agroecosystem of Illinois, USA. Biogeochemistry 93:7-30. doi:10.1007/s10533-008-9273-9

Di Toro, D.M., D.J. O'Connor, J.L. Mancini and R.V.Thomann, 1973. A preliminary phytoplankton-zooplankton-nutrient model of Western Lake Erie. In Systems Analysis \& Simulation in Ecology. Volume 3. Academic Press.

Dodds, W.K., 2006. Eutrophication and trophic state in rivers and streams. Limnology and Oceanography, 51, 671-680.

Duan, Q., Sorooshian, S., Gupta, V., 1992. Effective and efficient global optimization for conceptual rainfall-runoff models. Water Resources Research, 28(4), pp.1015-1031.

Dudgeon, D., Arthington, A.H., Gessner, M.O., Kawabata, Z.I., Knowler, D.J., Leveque, C., Naiman, R.J., Prieur-Richard, A.H., Soto, D., Stiassny, M.L.J., Sullivan, C.A., 2006. Freshwater biodiversity: importance, threats and conservation challenges. Biological Reviews, 81, 163-182.

Dungjen, T., Patch, D., 2014. Toledo-area water advisory expected to continue through Sunday as leaders await tests. The Blade. Published on Aug. 2, 2014. Available online: http://www.toledoblade.com/local/2014/08/02/City-of-Toledo-issues-do-no-drink-wateradvisery.html

Efstratiadis A, Koutsoyiannis, D., 2010. One decade of multi-objective calibration approaches in hydrological modeling: a review. Hydrological Sciences Journal. 55(1): 58-78. 
Einheuser, M.D., Nejadhashemi, A.P., Sowa, S.P., Wang, L., Hamaamin, Y.A., Woznicki, S.A. 2012. Modeling the effects of conservation practices on stream health. Science of the Total Environment, 435-436, 380-391

Evans-White, M.A., Dodds, W.K., Huggins, D.G., Baker, D.S., 2009. Thresholds in macroinvertebrate biodiversity and stoichiometry across water-quality gradients in Central Plains (USA) streams. Journal of the North American Benthological Society, 28, 855-868.

Evans-White, M.A., Haggard, B.E., Scott, J.T., 2014. A review of stream nutrient criteria development in the United States. Journal of Environmental Quality, 42, 1002-1014.

Foster, G. R., 2005. Revised Universal Soil Loss Equation, Version 2.0 (RUSLE2 2.0): Science Documentation. USDA-Agricultural Research Service, Washington, DC, pp 286.

Gassman, P. W., Reyes, M. R., Green, C. H., Arnold, J. G., 2007. The soil and water assessment tool: historical development, applications and future research directions, Transactions of the American Society of Agricultural and Biological Engineers 50 (4), 1211-1250.

Gaynord, J.D., and Findlay, W. I. 1995. Soil and phosphorus loss from conservation and conventional tillage in corn production. Journal of Environmental Quality 24: 734-741.

Gebremariam, S. Y., Martin, J.F., DeMarchi, C., Bosch, N.S., Confesor, R., Ludsin, S.A., 2014. A comprehensive approach to evaluating watershed models for predicting river flow regimes critical to downstream ecosystem services Environ. Modell. Softw. 71, 121-134.

Gesch, D., Evans, G., Mauck, J., Hutchinson, J., Carswell, Jr. W. J., 2009. The National MapElevation: U.S. Geological Survey Fact Sheet 2009-3053, 4 p. Last accessible online at http://ned.usgs.gov/; last accessed on September 18, 2013.

Haan, C.T., Allred, B., Storm, D.E., Sabbagh, G.J., Prabhu, S., 1995. Statistical procedure for evaluating hydrologic/water quality models. Trans. ASAE 38 (3), 725-733.

Jha, M.K., Gassman, P.W., 2014. Changes in hydrology and streamflow as predicted by a modelling experiment forced with climate models. Hydrological Processes 28, 2772-2781.

Johnson, M. V. V., M. L. Norfleet, J. D. Atwood, K. D. Behrman, J. R. Kiniry, J. G. Arnold, M. J. White, and J. Williams. 2015. The Conservation Effects Assessment Project (CEAP): a national scale natural resources and conservation needs assessment and decision support tool. IOP Conference Series: Earth and Environmental Science 25. doi: 10.1088/1755$1315 / 25 / 1 / 012012$

Kane, D.D., Conroy, J.D., Richards, P.R., Baker, D.B., Culver, D.A., 2014. Re-eutrophication of Lake Erie: correlations between tributary nutrient loads and phytoplankton biomass. Journal of Great Lakes Research, 40, 496-501.

Keitzer, S., Ludsin, S.A., Sowa, S., Annis, G., Daggupati, P., Froelich, A.M., Herbert, M.E., Johnson, M.V., Yen, H., White, M.J., Arnold, J.G., Sasson, A.M., Rewa, C.A., 2016. Thinking outside of the lake: Can controls on nutrient inputs into Lake Erie benefit stream conservation in its watershed? Journal of Great Lakes Research (accepted, in press).

Kaatz, M.R., 1955. "The Black Swamp: A Study in Historical Geography". Annals of the Association of American Geographers 45 (1): 1-35. doi:10.1111/j.14678306.1955.tb01481.x

Matthaei, C.D., Piggott, J.J., Townsend, C.R. 2010. Multiple stressors in agricultural streams: interactions among sediment addition, nutrient enrichment and water abstraction. Journal of Applied Ecology, 47, 639-649.

Mausbach, M.J., and Dedrick, A.R., 2004. The length we go: Measuring environmental benefits of conservation practices. Journal of Soil and Water Conservation 59(5):96-103. 
Michalak, A.M., Anderson, E.J., Beletsky, D., Boland, S., Bosch, N.S., Bridgemen, T.B., Chaffin, J.D., Cho, K., Confesor, R., Daloglu, I., DePinto, J.V., Evans, M.A., Fahnenstiel, G.L., He, L., Ho, J.C., Jenkins, L., Johengen, T.H., Kuo, K.C., LaPorte, E., Liu, X., McWilliams, M.R., Moore, M.R., Posselt, D.J., Richards, P.R., Scavia, D., Steiner, A.L., Verhamme, E., Wrigtht, D.M., Zagorski, M.A., 2013. Record-setting algal bloom in Lake Erie caused by agricultural and meteorological trends consistent with expected future conditions. Proceedings of the National Academy of Science, USA, 110, 6448-6452.

Miltner, R.J., 2010. A method and rationale for deriving nutrient criteria for small rivers and streams in Ohio. Environmental Management, 45, 842-855.

Miltner, R.J., Rankin, E.T., 1998. Primary nutrients and the biotic integrity of rivers and streams. Freshwater Biology, 40, 145-158.

Mitsch, William J.; James G. Gosselink (2007). Wetlands. John Wiley and Sons. pp. 65-66. ISBN 978-0-471-69967-5.

Molder, B., Cockburn, J., Berg, A., Lindsay, J., and Woodrow, K. 2015. Sediment-assisted nutrient transfer from a small, no-till tile drained watershed in Southwestern Ontario, Canada. Agricultural Water Management 152: 31-40.

Moriasi, D. N., Arnold, J. G., Liew, M. W. V., Bingner, R. L., Harmel, R. D., and Veith, T. L., 2007. Model evaluation guidelines for systematic quantification of accuracy in watershed simulations, Transactions of the ASABE, 50(3), 885-900.

Nash, J.E., and Sutcliffe., J.V., 1970. River flow forecasting through conceptual models: Part I. A discussion of principles. J. Hydrol. 10(3): 282-290.

Neitsch, S.L., Arnold, J. G., Kiniry, J. R., R, W. J., 2011. Soil \& Water Assessment Tool Theoretical Documentation Version 2009. Texas Water Resource Institute Technical Report No. 406, Texas A \& M University System.

Richter, B.D., Braun, D.P., Mendelson, M.A., Master, L.L., 1997. Threats to imperiled freshwater fuana. Conservation Biology, 11, 1081-1093.

Runkel, R., Crawford, C., Cohn, T., 2004. Load Estimator (LOADEST): A Fortran Program for Estimating Constituent Loads in Streams and Rivers 2004. US Geological Survey Techniques and Methods Book, 4.

Santhi, C., Arnold, J.G, Williams, J.R., Dugas, W.A., Srinivasan, R., and Hauck, L.M., 2001. Validation of the SWAT Model on A Large River Basin with Point and Nonpoint Sources, Journal of the American Water Resources Association, 37, 1169-1188.

Scavia, D., M. Kalcic, R. L. Muenich, N. Aloysius, C. Boles, R. Confessor, J. DePinto, M. Gildow, J. Martin, J. Read, T. Redder, S. Sowa, Y. Wang, H. Yen, 2016. Shaping Lake Erie agriculture nutrient management via scenario development. University of Michigan, Ann Arbor. http://tinyurl.com/pp4umuz

Seibert, J., and J. J. McDonnell, 2002. On the dialog between experimentalist and modeler in catchment hydrology: Use of soft data for multicriteria model calibration, Water Resour. Res., 38(11), 1241, doi:10.1029/2001WR000978.

Servat, E., Dezetter, A., 1991. Selection of calibration objective functions in the context of rainfall-runoff modeling in a Sudanese savannah area. Hydrol. Sci. J 36, 307-330.

Schilling, K.E. 2002. Chemical transport from paired agricultural and restored prairie watersheds. J. Environ. Qual. 31:1184-1193. doi:10.2134/jeq2002.1184

Smith, V.H., Tilman, G.D., Nekola, J.C., 1999. Eutrophication: impacts of excess nutrient inputs on freshwater, marine, and terrestrial ecosystems. Environmental Pollution, 100, 179-196. 
Srinivasan, R., Zhang, X., Arnold, J., 2010. SWAT ungauged: Hydrological budget and crop yield predictions in the upper Mississippi River basin. Transactions of the ASABE 53, $1533-1546$.

SWAT Literature Database Website, https://www.card.iastate.edu/swat_articles/, Last accessed 4/2/2014, 4:58 pm.

Taylor, J.M., King, R.S., Pease, A.A., Winemiller, K.O., 2014. Nonlinear response of stream ecosystem structure to low-level phosphorus enrichment. Freshwater Biology, 59, 969-984.

Tolson, B. A., Shoemaker, C. A., 2007. Dynamically dimensioned search algorithm for computationally efficient watershed model calibration. Water Resources Research, 43(1), pp.1-16.

Townsend, C.R., Uhlmann, S.S., Matthaei, C.D., 2008. Individual and combined responses of stream ecosystems to multiple stressors. Journal of Applied Ecology, 45, 1810-1819.

USDA-SCS, 1972. National Engineering Handbook, Hydrology, Section 4, Chapter 4-10. Washington, D. C.: Soil Conservation Service.

USDA-National Agricultural Statistics Service (NASS), 2011. Annual report of cash rents per acre, http://www.nass.usda.gov/Statistics_by_State/Ohio/Publications/Reports_by_Title/cshrnt11. pdf (last available Jan 11, 2016).

USDA-National Agricultural Statistics Service (NASS), 2014. http://www.nass.usda.gov/

USDA - Natural Resources Conservation Service (NRCS), 1995. Soil Survey Geographic (SSURGO) Database - Data Use Information. Misc. Publication No. 1527. National Soil Survey Center, Lincoln, NE.

USDA - Natural Resources Conservation Service (NRCS), 2011. Assessment of the effects of conservation practices on cultivated cropland in the Great Lakes region, Conservation Effects Assessment Project (CEAP). http://www.nrcs.usda.gov/Internet/FSE_DOCUMENTS/stelprdb1045480.pdf

USDA - Natural Resources Conservation Service (NRCS), 2012. FY2013 Practice Payment Schedule for EQIP/WHIP, Guidance Document. http://www.nrcs.usda.gov/Internet/FSE_DOCUMENTS/nrcs141p2_035967.pdf

USDA - Natural Resources Conservation Service (NRCS), 2014. Western Lake Erie Basin (WLEB) CEAP project, Semiannual Progress Report.

USDA - Natural Resources Conservation Service (NRCS), 2015. Western Lake Erie Basin (WLEB) CEAP project, Semiannual Progress Report.

USDA - Natural Resources Conservation Services (NRCS), 2016. Effects of conservation practice adoption on cultivated cropland acres in Western Lake Erie Basin, 2003-06 and 2012. 120 pp. http://www.nrcs.usda.gov/Internet/FSE_DOCUMENTS/nrcseprd889806.pdf

USEPA, 2006. Wadeable streams assessment. USEPA-841-B-06-002. USEPA, Washington, D.C.

USEPA, 2015. https://epahawqs.tamu.edu/projects

USEPA, 2016. National rivers and stream assessment 2008-2009: a collaborative survey. USEPA-841-R-I6-007. USEPA, Washington, D.C.

Vörösmarty, C.J., McIntyre, P.B., Gessner, M.O., Dudgeon, D., Prusevich, A., Green, P., Glidden, S., Bunn, S.E., Sullivan, C.A., Liermann, C.R., Davies, P.M., 2010. Global threats to human water security and river biodiversity. Nature, 467, 555-561. 
Wagenhoff, A., Townsend, C.R., Matthaei, C.D., 2012. Macroinvertebrate responses along broad stressor gradients of deposited fine sediment and dissolved nutrients: a stream mesocosm

Wagenhoff, A., Townsend, C.R., Phillips, N., Matthaei, C.D., 2011. Subsidy-stress and multiplestressor effects along gradients of deposited fine sediment and dissolved nutrients in a regional set of streams and rivers. Freshwater Biology, 56, 1916-1936.

Wang, L., Lyons, J., Kanehl, P., 2002. Effects of watershed best management practices on habitat and fish in Wisconsin streams. Journal of the American Water Resources Assocation, 38, 663-680.

Wang, L., Lyons, J., Kanehl, P., 2006. Habitat and fish responses to multiple agricultural best management practices in a warm water stream. Journal of the American Water Resources Association, 42, 1047-1062.

Wang, L., Robertson, D.M., Garrison, P.J., 2007. Linkages between nutrients and assemblages of macroinvertebrates and fish in wadeable streams: implication to nutrient criteria development. Environmental Management, 39, 194-212.

White, K. L., Chaubey, I., 2005. Sensitivity analysis, calibration, and validations for a multisite and multivariable SWAT model. Journal of the American Water Resources Association, 41(5), 1077-1089.

White, M. J., Santhi, C., Kannan, N., Arnold, J. G., Harmel, R. D., Norfleet, L., Allen, P., DiLuzio, M., Wang, X., Atwood, J. D., Haney, E., Johnson, M., 2014. Nutrient delivery from the Mississippi River to the Gulf of Mexico and effects of cropland conservation. Journal of Soil and Water Conservation 69(1):26-40.

White, M., R. D. Harmel, H. Yen, J. G. Arnold, M. Gambone, and R. Haney, 2015a. Development of Sediment and Nutrient Export Coefficients for U.S. Ecoregions. Journal of the American Water Resources Association, 51(3): 758-775. DOI: 10.1111/jawr.12270

White, M., M. Gambone, H. Yen, J. G. Arnold, R. D. Harmel, C. Santhi, and R. Haney, 2015b. Regional Blue and Green Water Balances and Use by Selected Crops in the US. Journal of the American Water Resources Association, in press.

Williams, J. W., Izaurralde, R. C., Steglich, E. M., 2012. Agricultural Policy/Environmental EXtender Model Theoretical Documentation Version 0806. $131 \mathrm{p}$.

Yen, H., Jeong, J., Tseng, W., Kim, M., Records, R., and Arabi, M., 2014a. Computational Procedure for Evaluating Sampling Techniques on Watershed Model Calibration. J. Hydrol. Eng., 20(7). DOI: 10.1061/(ASCE)HE.1943-5584.0001095 , 04014080.

Yen, H., Bailey, R. T., Arabi, M., Ahmadi, M., White, M. J., Arnold, J. G., 2014b. The Role of Interior Watershed Processes in Improving Parameter Estimation and Performance of Watershed Models. Journal of Environmental Quality, published online. doi:10.2134/jeq2013.03.0110

Yen, H., Wang, X., Fontane, D. G., Harmel, R. D., Arabi, M., 2014c. A framework for propagation of uncertainty contributed by parameterization, input data, model structure, and calibration/validation data in watershed modeling, Environmental Modelling and Software, 54, pp. 211-221, doi: 10.1016/j.envsoft.2014.01.004.

Yen, H., M. J. White, J. C. Ascough III, D. R. Smith, J. G. Arnold, 2016. Augmenting Watershed Model Calibration with Incorporation of Ancillary Data Sources and Qualitative Soft Data Sources. Journal of the American Water Resources Association, (JAWRA) 52(3), pp. 788798. DOI: $10.1111 / 1752-1688.12428$ 


\section{Acknowledgements}

964 This project was funded by grants from the United States Department of Agriculture 965 Natural Resources Conservation Service (USDA-NRCS) Conservation Effects Assessment

966 Project (CEAP) - Wildlife and Cropland components. USDA is an equal opportunity employer 967 and provider! 
Table 1: General information of calibration/validation data sources

\begin{tabular}{|c|c|c|c|c|c|}
\hline Station ID & HUC-8 Number & $\begin{array}{c}\text { Drainage Area } \\
(\mathrm{km} 2)\end{array}$ & Location & $\begin{array}{l}\text { Data Source } \\
\text { (Streamflow) }\end{array}$ & $\begin{array}{l}\text { Data Source } \\
\text { (Nutrients) }\end{array}$ \\
\hline 4176500 & 041000 & $2680(11.3 \%)$ & $\begin{array}{ll}\text { River Raisin } & \text { near } \\
\text { Monroe, } & \text { MI }\end{array}$ & $\begin{array}{l}\text { Heidelberg College River } \\
\text { Studies }\end{array}$ & Heidelberg U \\
\hline 4178000 & 04100003 (St. Joseph) & $1541(6.5 \%)$ & $\begin{array}{l}\text { St. Joseph River near } \\
\text { Newville, IN }\end{array}$ & $\begin{array}{l}\text { United States Geologic } \\
\text { Survey }\end{array}$ & USGS \\
\hline LES040-0007 & 04100004 (St. Marys) & $1311(5.5 \%)$ & St. Marys River & $\begin{array}{l}\text { Indiana Department of } \\
\text { Environmental Management }\end{array}$ & $\begin{array}{l}\text { Department of Environmental } \\
\text { ent }\end{array}$ \\
\hline 4193500 & 0410 & 16 & $\begin{array}{l}\text { Maumee River } \\
\text { Waterville, OH }\end{array}$ & $\begin{array}{l}\text { Heidelberg College River } \\
\text { Studies }\end{array}$ & $\begin{array}{l}\text { Heidelberg University, USGS \& OH } \\
\text { Environmental Protection Agency }\end{array}$ \\
\hline 41980 & 04100011 & 2015 & $\begin{array}{l}\text { Sandusky River near } \\
\text { Fremont, OH }\end{array}$ & $\begin{array}{l}\text { Heidelberg College River } \\
\text { Studies }\end{array}$ & $\begin{array}{l}\text { Heidelberg University, USGS \& OH } \\
\text { Environmental Protection Agency }\end{array}$ \\
\hline
\end{tabular}

970 The selected representative gauge stations are used in calibration/validation processes where details of the selection procedure can be found in Daggupati et al. (2015). 


\begin{tabular}{lcrr}
\hline Categories of General & \multirow{2}{*}{ NSE } & \multicolumn{2}{c}{ PBIAS $(\%)$} \\
\cline { 2 - 4 } Performance Rating & & PBIAS $< \pm 10$ & Sediment \& Nutrients \\
\hline Very Good & $0.75<\mathrm{NSE} \leq 1.00$ & PBIAS $< \pm 25$ \\
Good & $0.65<\mathrm{NSE} \leq 0.75$ & $\pm 10 \leq$ PBIAS $< \pm 15$ & $\pm 25 \leq$ PBIAS $< \pm 40$ \\
Satisfactory & $0.50<\mathrm{NSE} \leq 0.65$ & $\pm 15 \leq$ PBIAS $< \pm 25$ & $\pm 40 \leq$ PBIAS $< \pm 70$ \\
Unsatisfactory & $\mathrm{NSE} \leq 0.50$ & PBIAS $\geq \pm 25$ & PBIAS $\geq \pm 70$ \\
\hline $\begin{array}{l}\text { NSE: Nash-Sutcliffe efficiency coefficient } \\
\text { PBIAS: Percent bias }\end{array}$ & &
\end{tabular}

980

981

982

983

984

985

986

987

988

989

990

991

992

993

994

995 


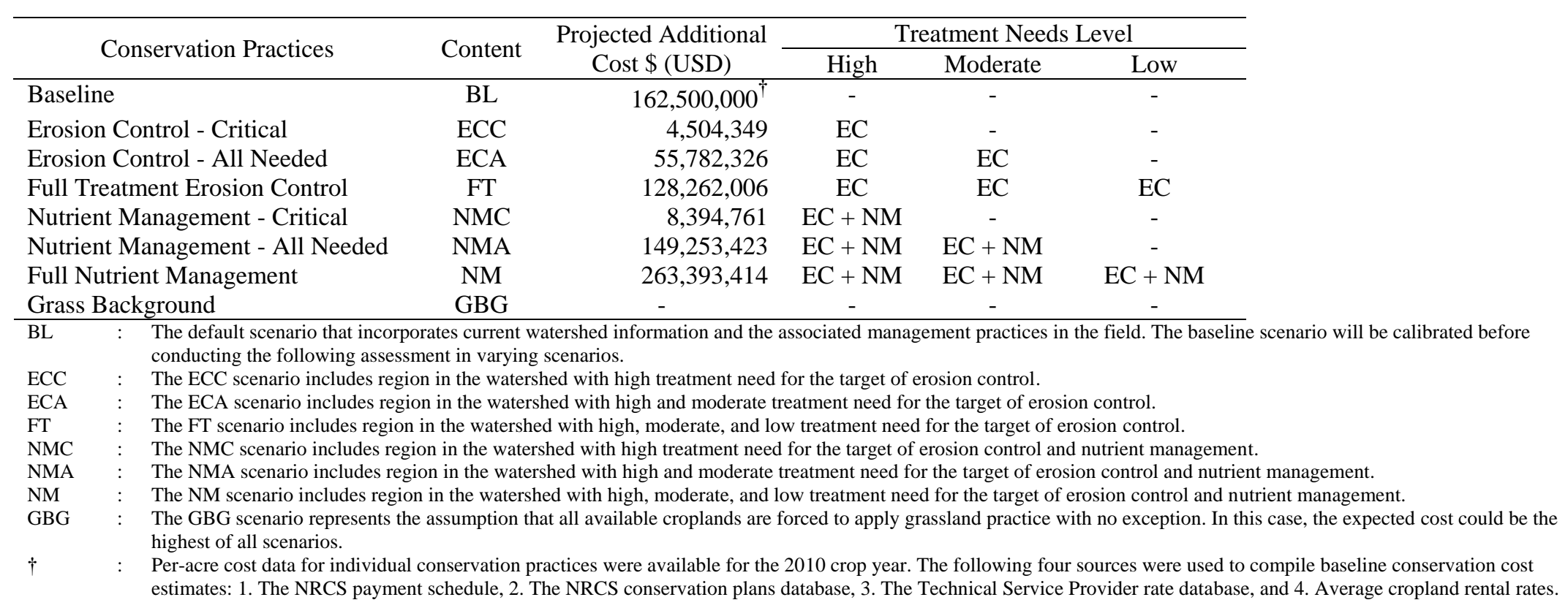


1002 Table 4: Statistics of the calibration (1990-1999) and validation (2000-2006) periods

\begin{tabular}{lccccc}
\hline \multirow{2}{*}{ Station } & \multicolumn{2}{c}{ Streamflow } & Sediment & TP & TN \\
\cline { 2 - 5 } & NSE & PBIAS (\%) & PBIAS (\%) & PBIAS (\%) & PBIAS (\%) \\
\hline Raisin & $0.70^{\dagger} / 0.43^{\star}$ & $-11.76 /-26.07$ & $16.71 / 35.46$ & $-3.55 /-22.74$ & $14.66 / 3.59$ \\
St. Joseph & $0.73 / 0.74$ & $22.70 / 18.66$ & $-10.43 /-20.3$ & $5.33 / 4.95$ & $-25.39 /-68.71$ \\
St. Marys & $0.54 / 0.43$ & $17.94 / 25.25$ & $17.99 / 19.57$ & $6.52 / 9.42$ & $8.23 / 21.00$ \\
Maumee & $0.87 / 0.88$ & $18.03 / 13.56$ & $10.07 /-10.59$ & $8.42 / 3.42$ & $16.87 / 13.27$ \\
Sandusky & $0.82 / 0.75$ & $18.67 / 7.00$ & $18.63 /-35.01$ & $-12.78 / 0.61$ & $-15.26 /-12.37$ \\
\hline$\dagger:$ Quantitative measures on the left-hand side represent the statistics for the calibration period. & \\
†: Quantitative measures on the right-hand side represent the statistics for the validation period. &
\end{tabular}

1006

1007

Table 5. Coefficient estimates (95\% confidence interval) from multilevel models describing 1008 the effects of additional investment (Cost), including nutrient management (Nutrient

1009 management), and their interaction (Cost $\mathrm{x}$ nutrient management) on the amount of the

1010 watershed that is improved according to nutrient criteria for total phosphorus (TP) and total

1011 nitrogen $(\mathrm{TN})$. Estimates were considered significant if bootstrapped $(\mathrm{n}=10,000)$ confidence

1012 intervals did not include zero.

\begin{tabular}{lcccc}
\hline Nutrient & Intercept & Cost & Nutrient Management & Cost x Nutrient Management \\
\hline TP & $0.91(0.27,1.57)$ & $0.072(0.063,0.079)$ & $-0.15(-1.07,0.78)$ & $-0.02(-0.029,-0.011)$ \\
TN & $0.029(-0.27,0.31)$ & $0.008(0.005,0.01)$ & $0.40(0.03,0.80)$ & $0.004(0.0005,0.008)$ \\
Both TN \& NP & $1.13(0.56,1.68)$ & $0.08(0.075,0.089)$ & $-0.17(-0.9376,0.6494)$ & $-0.02(-0.03,-0.015)$ \\
\hline
\end{tabular}

1013

1014

1015

1016

1017

1018

1019

1020

1021 


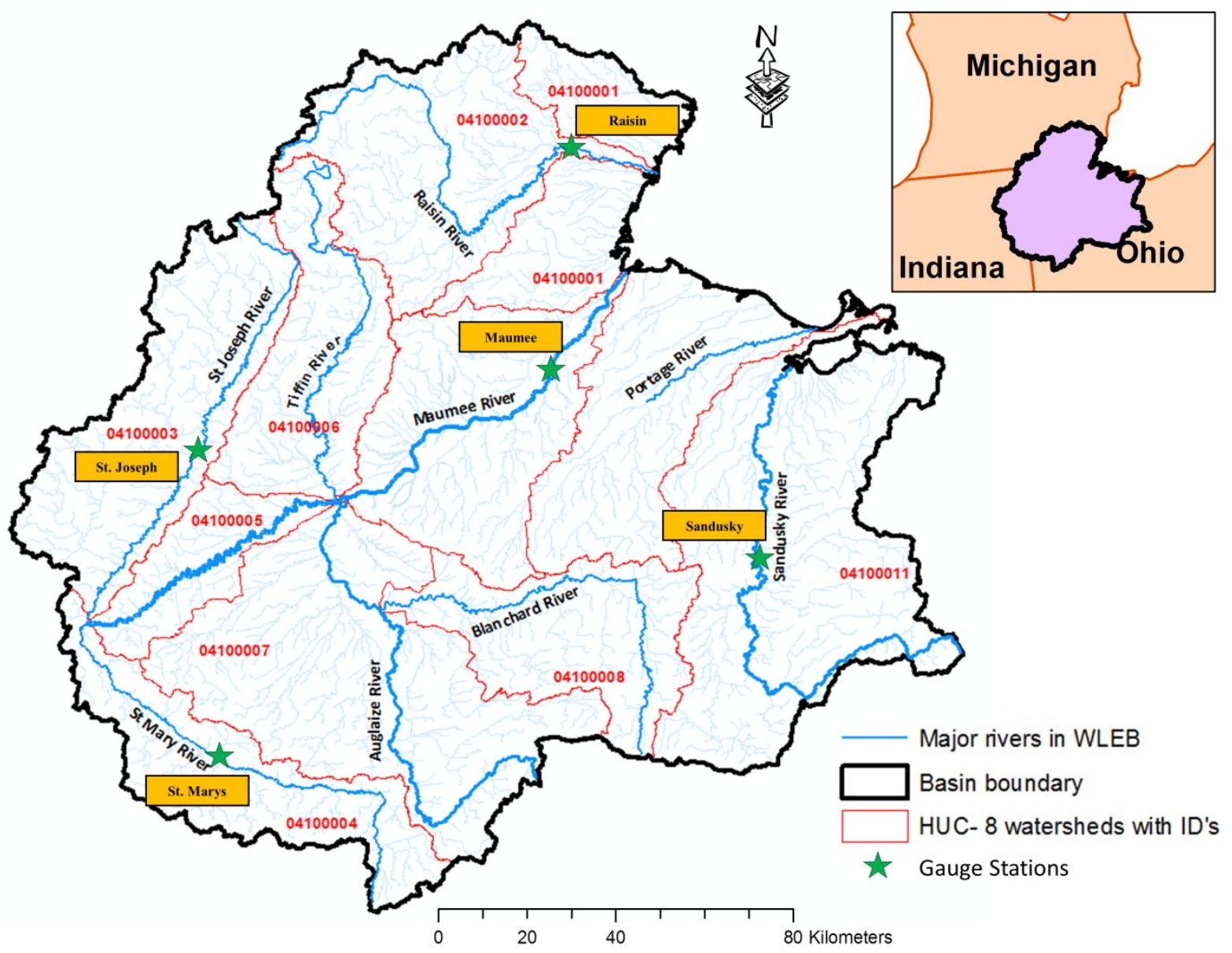

Figure 1. Location of the Western Lake Erie Basin and the representative gauging stations. 

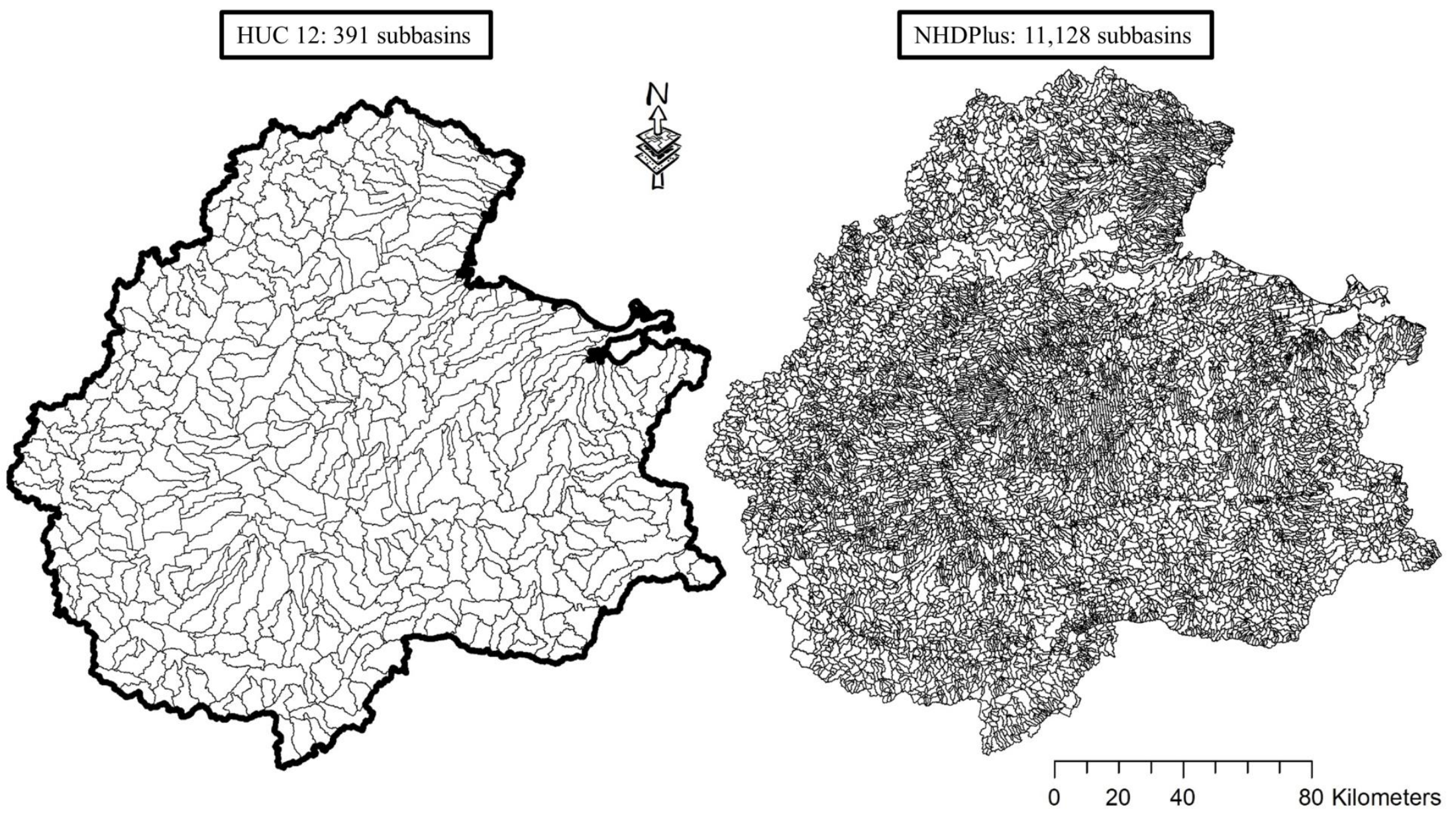

1026

1027

1028

1029

1030

1031

Figure 2. The HUC-12 and the NHDPlus models in WLEB (Daggupati et al., 2015). 

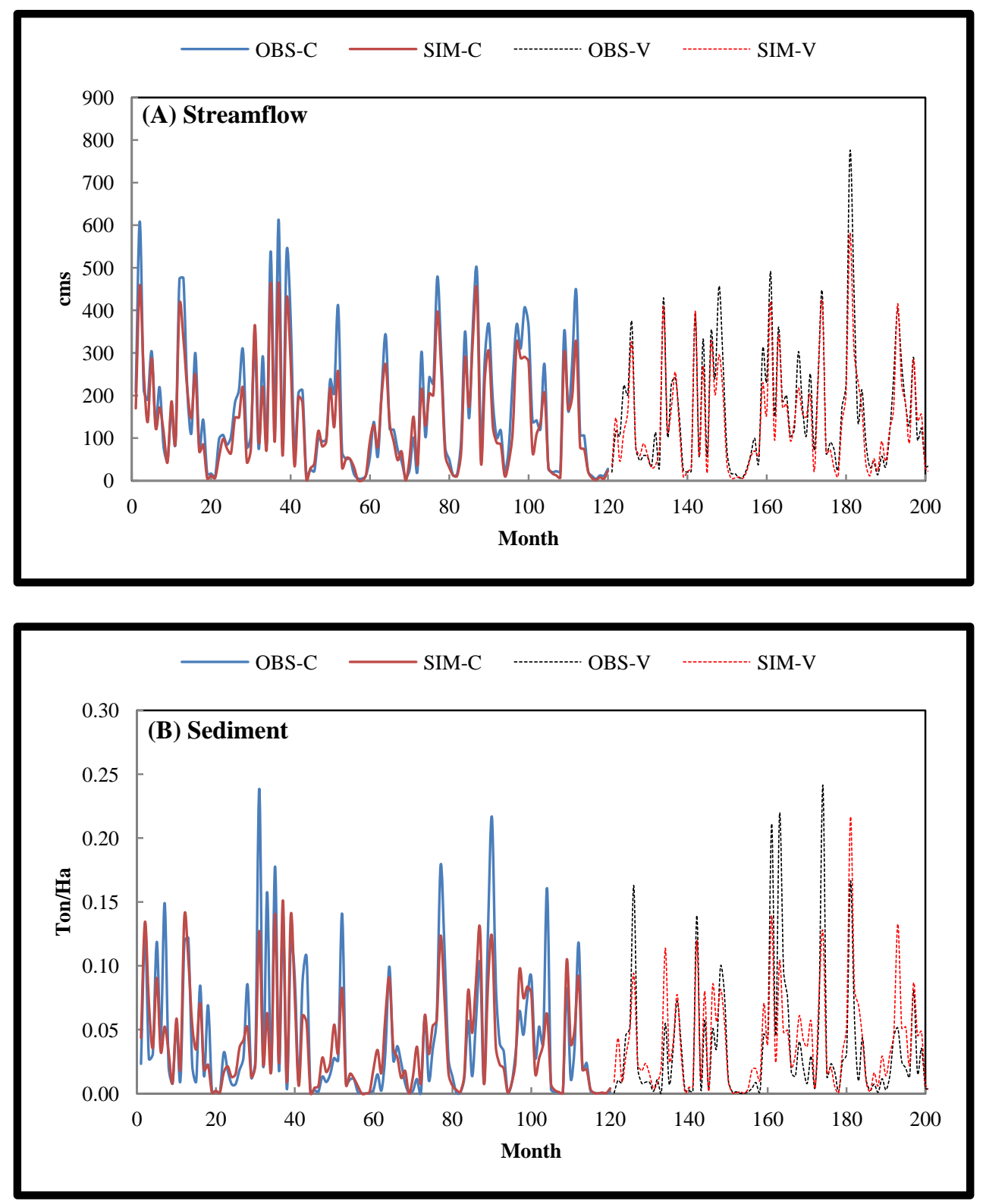

1034

1035

1036

1037

1038
Figure 3. Calibration and validation results of temporal processes of Maumee Station: (A) streamflow; (B) sediment; (C) total phosphorus; and (D) total nitrogen. (OBS: observation data; SIM: simulation output; -C: calibration period; -V: validation period) 

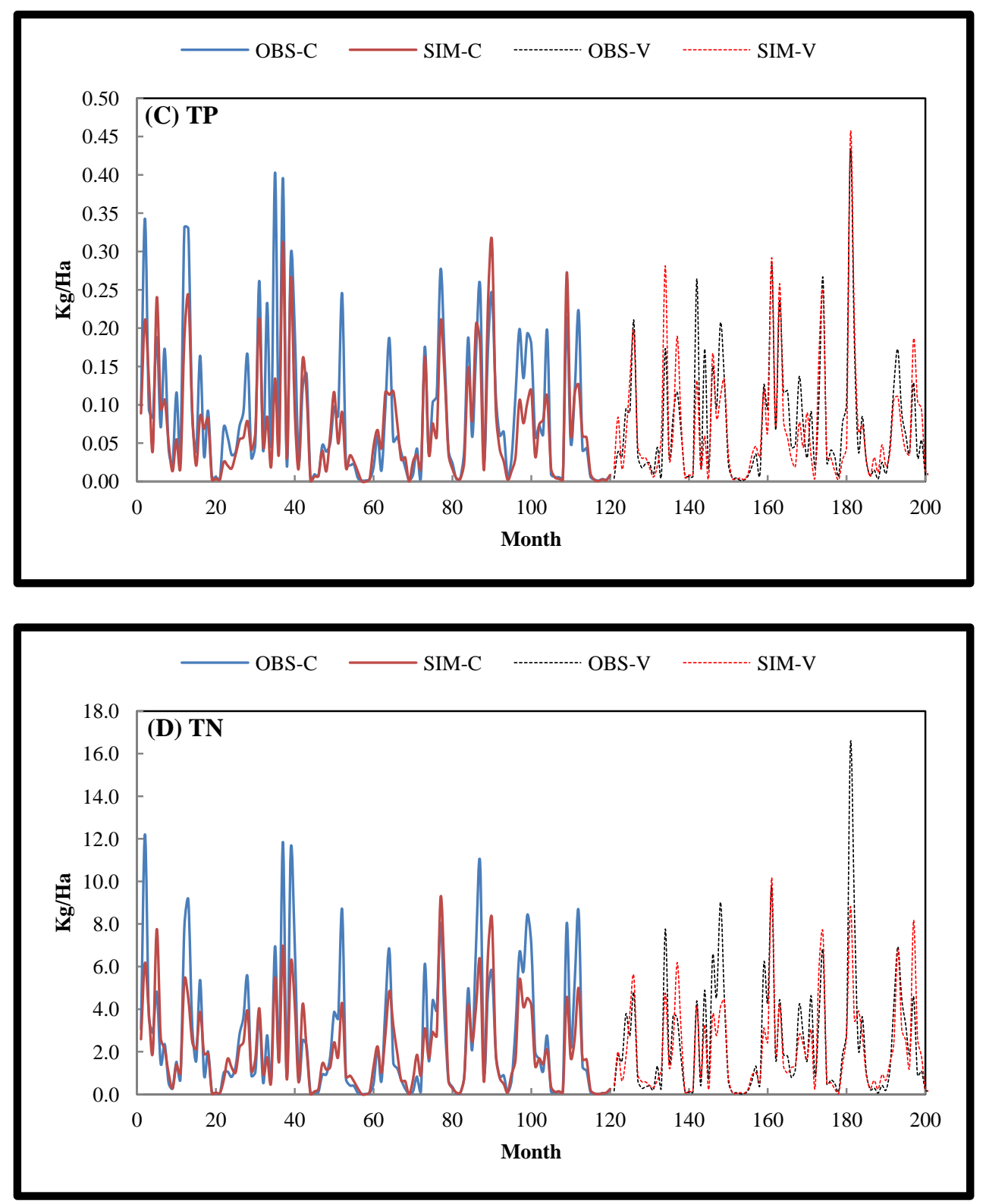

1041 Figure 3. (continued)

1042

1043

1044

1045

1046

1047 

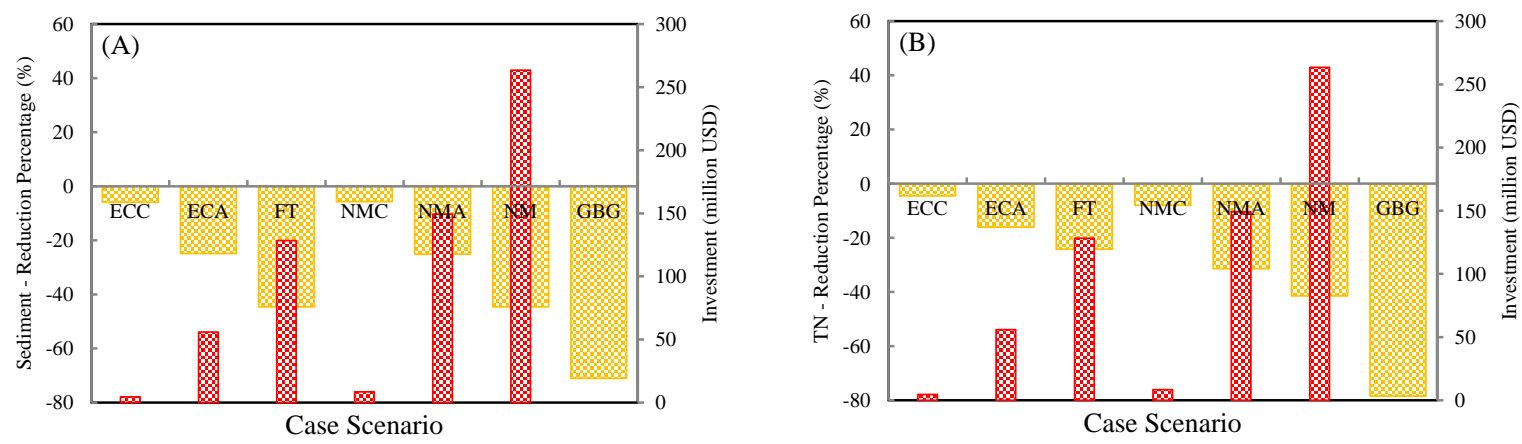

1048
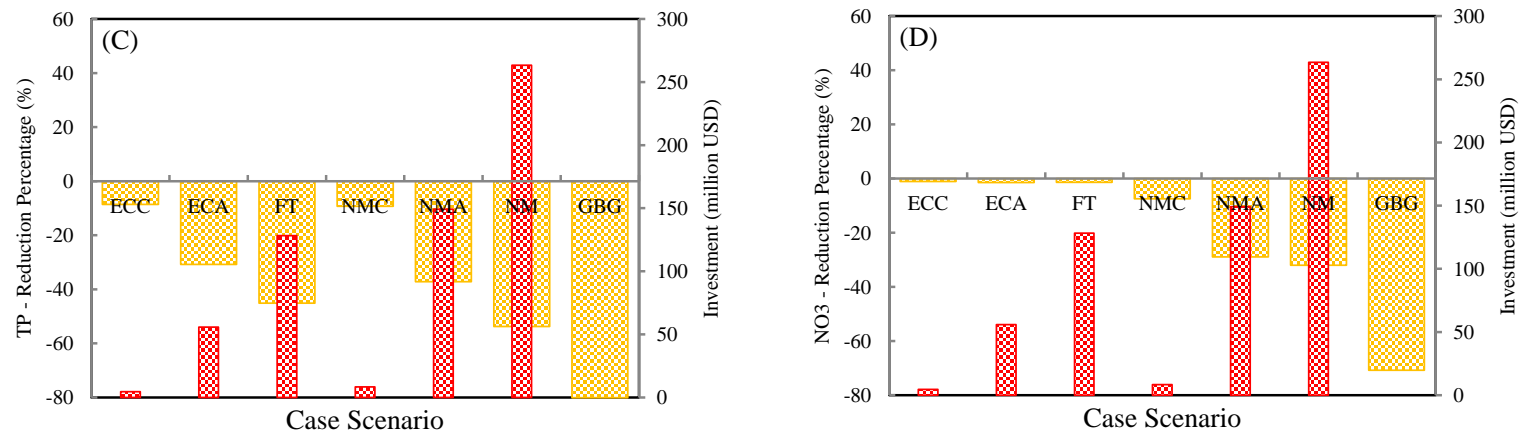

1049
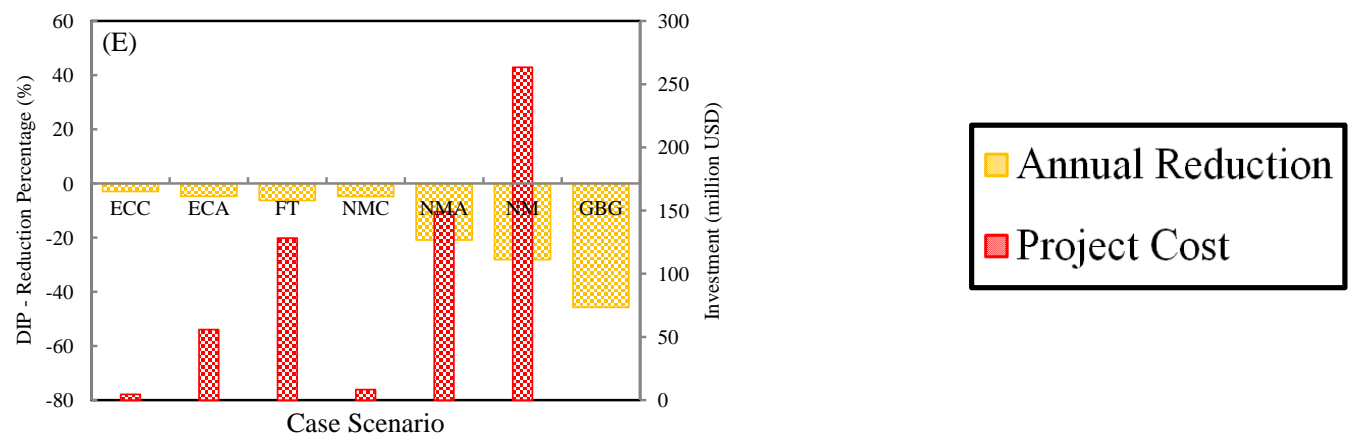

Figure 4. Demonstration of percentage reduction of targeted output responses with alternative conservation scenarios in terms of projected additional cost (\$ million, USD): (A) Sediment; (B) Total nitrogen; (C) Total phosphorus; (D) $\mathrm{NO}_{3}$; and (E) Dissolved phosphorus. (ECC: Erosion Control - Critical; ECA: Erosion Control - All Needed; FT: Full Treatment Erosion; NMC: Nutrient Management - Critical; NMA: Nutrient Management - All Needed; NM: Full Nutrient Management; GBG: Grass Background) 

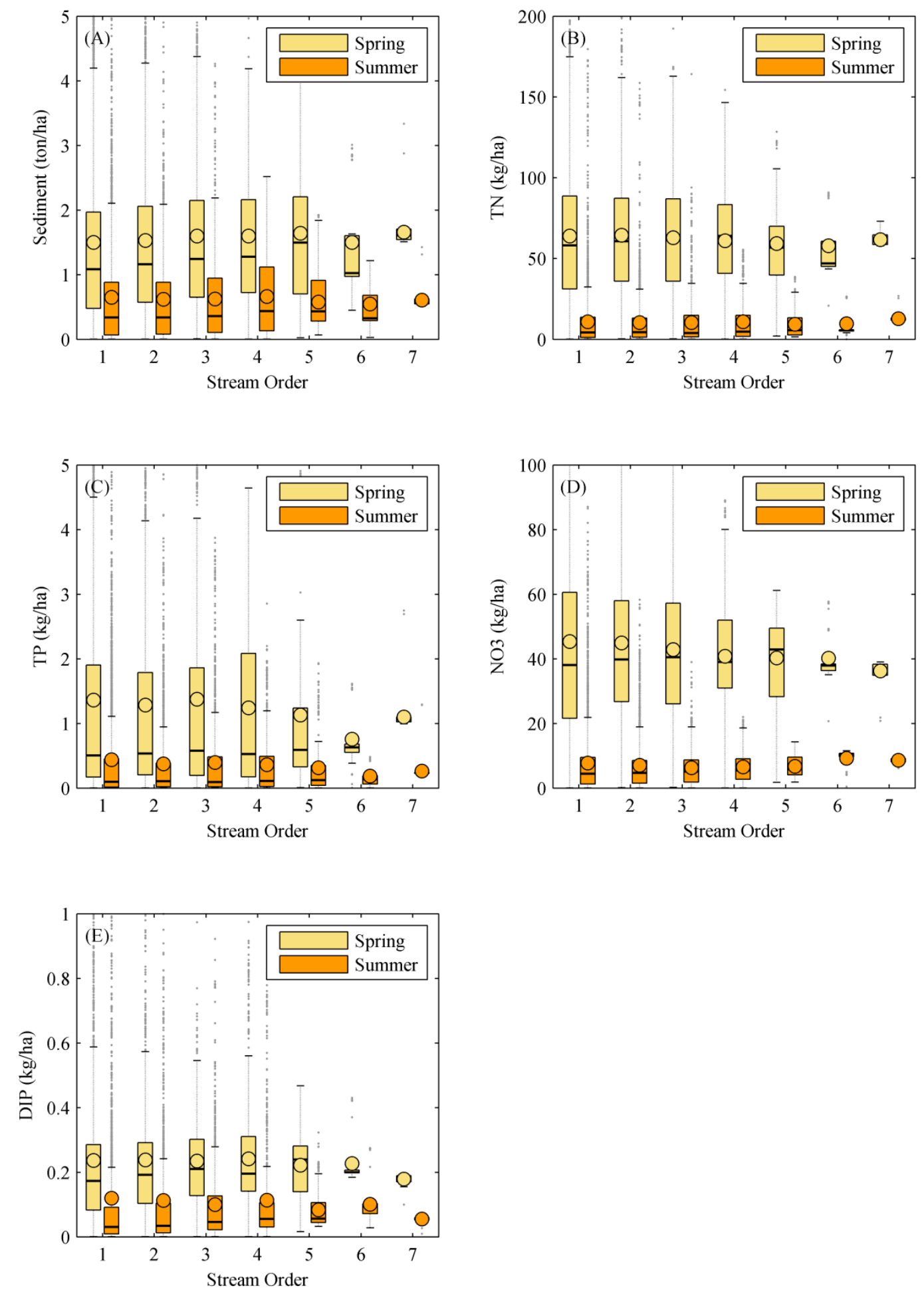
(Baseline scenario): (A) Sediment; (B) Total nitrogen; (C) Total phosphorus; (D) $\mathrm{NO}_{3}$; and (E) 

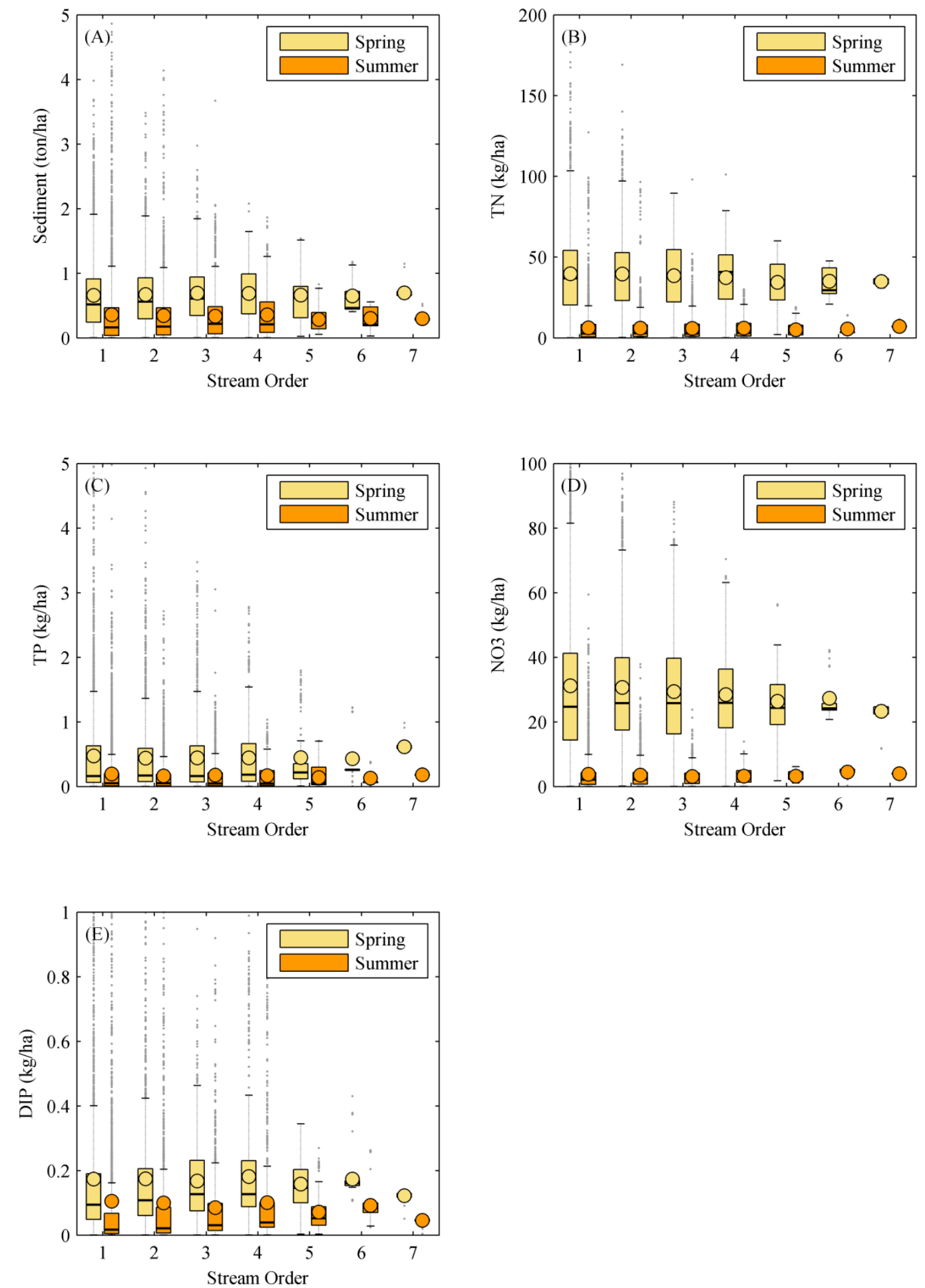

Figure 6. Model responses for spring and summer seasons by different stream order (NM 
A)

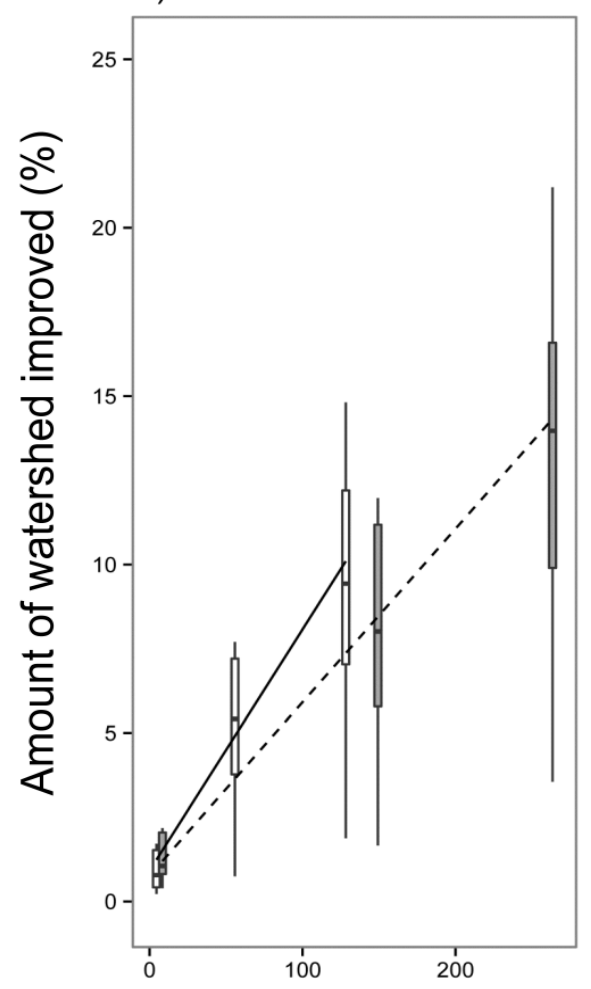

B)

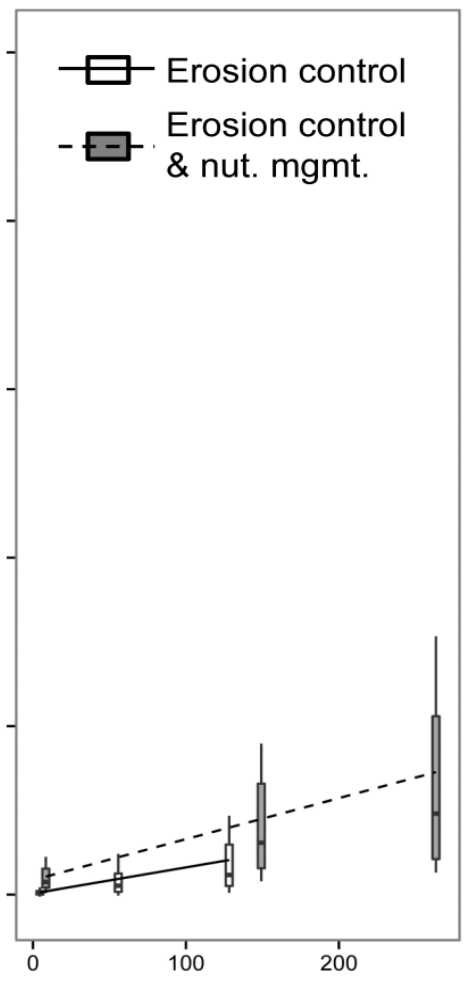

C)

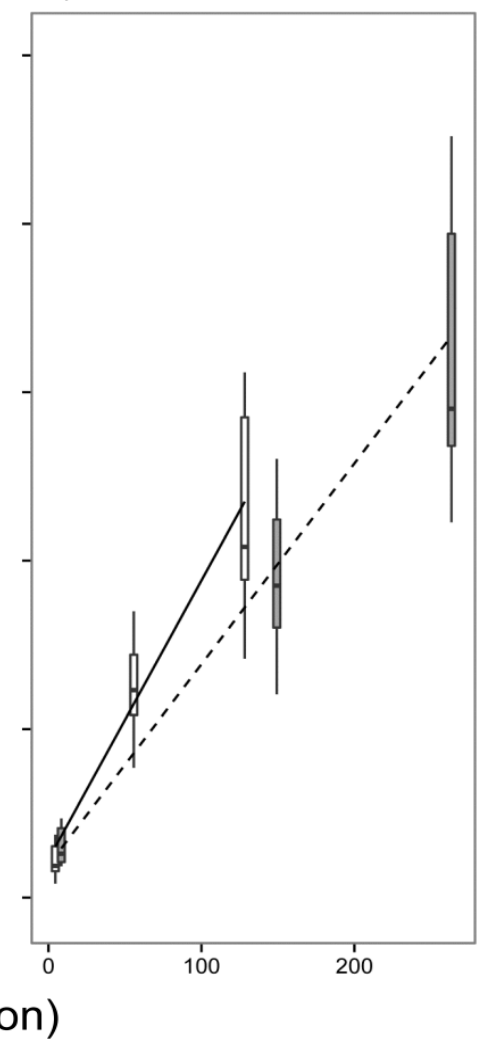

1071

Additional investment (\$ million)

Figure 7. Amount of the watershed in which stream biological conditions improved as a

1073 result of additional investment in conservation practices reducing nutrient enrichment: (A)

1074 improved percentage for streams that were above TP criteria; (B) improved percentage for

1075 streams that were above TN criteria; and (C) improved percentage for streams that were above

1076 both TP and TN. Boxplots represent the interquartile range of improvements across nutrient

1077 criteria with whiskers extending to the $10^{\text {th }}$ and $90^{\text {th }}$ percentiles. Lines show the predicted 1078 relationship between additional investment for conservation scenarios that included only erosion 1079 control practices (solid line) and scenarios that included erosion control and nutrient 1080 management practices (dashed line). 


\section{Appendix A. SWAT-SAS}

1083

In general SWAT application, SPCON is one of the important parameters that associated

1084 with the sediment transportation process. By default, users can only alter SPCON value for the

1085 entire watershed. However, a single value of SPCON may not be sufficiently representative if the

1086 targeted watershed is composed of wide variety of geographical characters (e.g., rapidly

1087 changing slope among subbasins). In this study, SWAT-SAS (Subregional Adjustment of

1088 Sediment) is developed to solve the issue so that not only the sediment loss can be simulated

1089 more accurately, nutrient load such as total phosphorus prediction can also be more

1090 representative. By adding an additional line at the end of each *.rte file, users can specify

1091 customized SPCON values at subbasin level.

1092

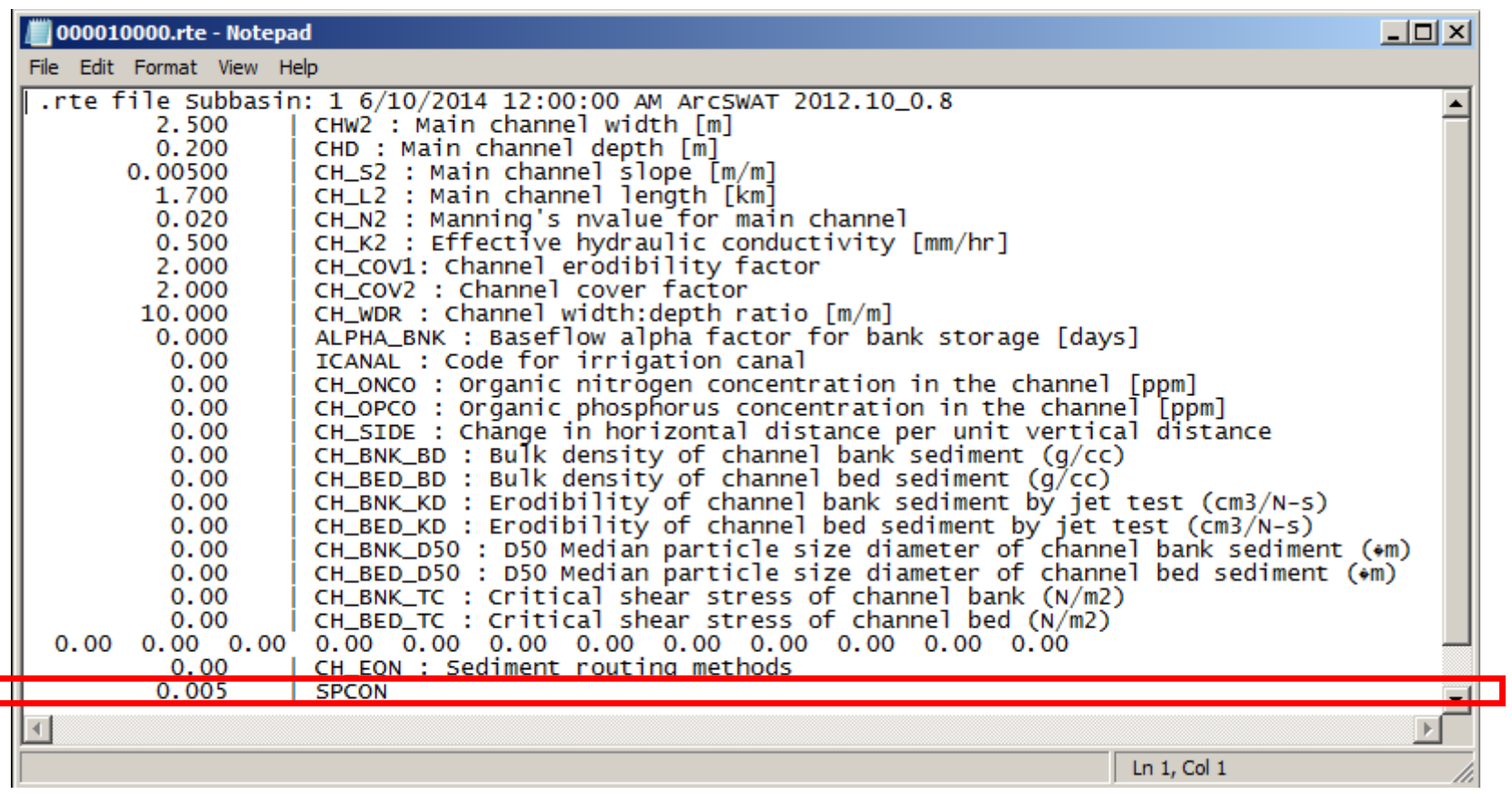

1093

1094 


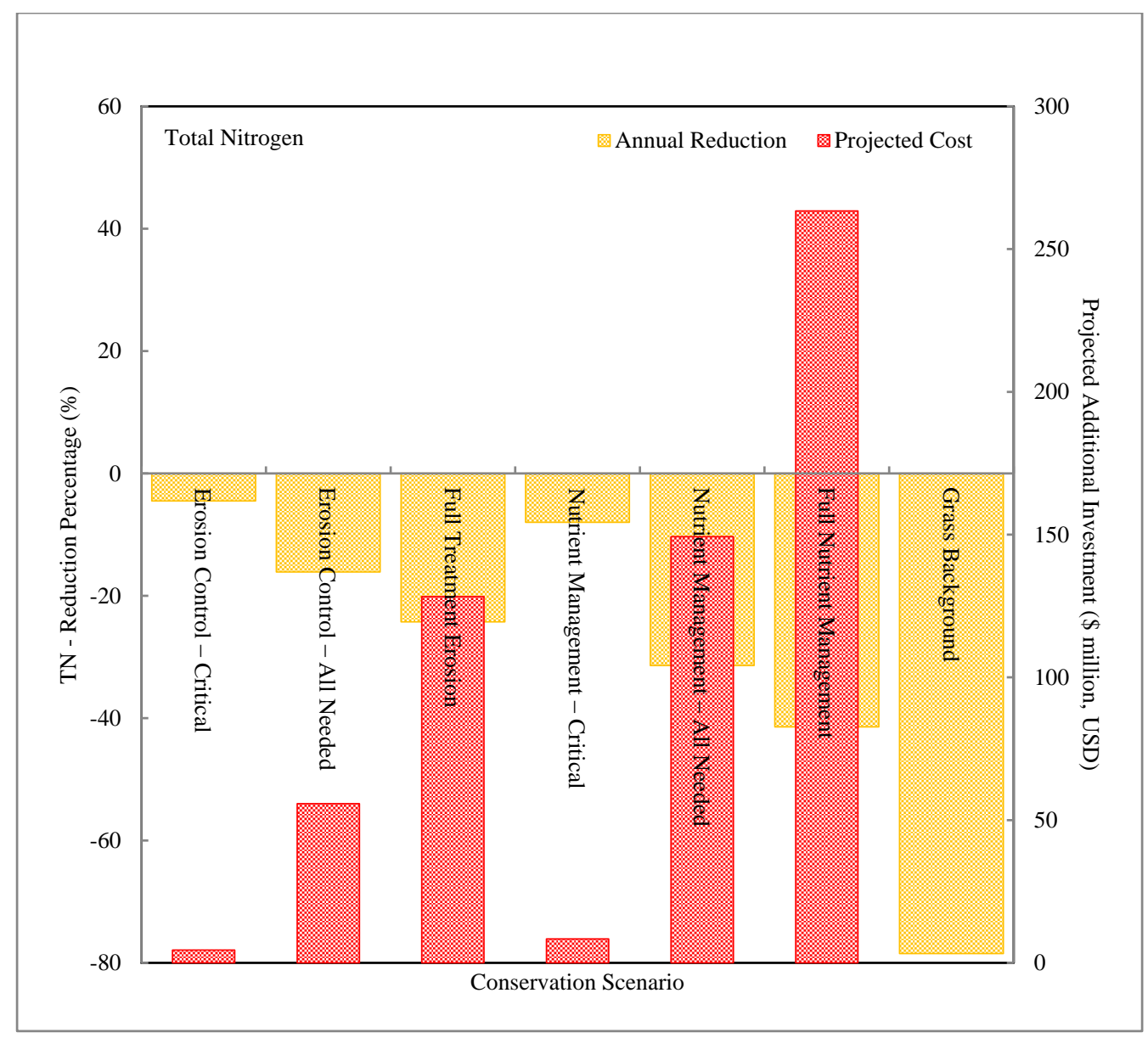

